\title{
Game of Thrones
}

\section{The Chess Set of Charlemagne in Context}

\author{
Lucinia Speciale
}

for Ferdinando Bologna in memoriam

Since the High Middle Ages, southern Italy has been a no man's land of diverse cultures and differing ideologies of power. A particularly notable example of the cross-pollination among these can be seen in a small group of ivory statuettes created at the beginning of the 12th century in one of the artisan workshops active in the region. For a long time, the treasury of Saint-Denis Abbey has preserved a set of chess pieces noted for their exceptional dimensions and shapes, all sculpted from elephant ivory (Figure. 9.1). The record filed on 18 January 1794 at the Cabinet of Antiquities (the original core of the current department of Coins, Medals, and Antiquities at the Bibliothèque nationale de France in Paris) describes the set as:

16 ivory pieces - formerly known as Charlemagne's chess set because it was assumed that they were among the gifts that the caliph Aaron Raschild sent to this emperor. ${ }^{1}$

The reference to Harun al-Rashid's gift is most likely an attempt to explain the exotic aspect of certain of the figures by associating them with the famous exchange of messengers between the Carolingian emperor and the Abbasid caliph. Much older accounts attributed the chess set to Charlemagne, as attested by the first mention of the pieces at Saint-Denis in a 1505 inventory: "A

1 "16 pièces d'yvoire - que l'on appelloit anciennement les échecs de Charlemagne parce que l'on supposait qu'elles faisaient partie des présens que le calife Aaron Raschild envoya à cet empereur." See: Blaise de Montesquiou-Fezenzac, Le Trésor de Saint-Denis 2 (Paris 1977), pp. $213^{-15}$. 
whole set of chess of ivory ... which belonged to Charlemagne."2 Likewise, Jean Doublet noted in his Histoire de l'abbaye de Saint-Denis en France: "This devoted king and emperor gave ... a rich psaltery written in golden letters, and an ivory chess game whose pieces are large."3

Finally, in 1838 Marion Du Mersan wrote:

On this board we see different antique ivory pieces for a game of chess. Sixteen of these pieces were found in the treasury of Saint-Denis. They are thought to come from a chess set given to Charlemagne by the caliph Harun al-Rashid. Fifteen of the pieces are less ancient. In the back row are the two kings and two queens. One of the kings is in a crenelated structure, dressed in regal clothing, holding a sceptre and seated on a throne while two valets hold back the curtains. The other king is in a structure without merlons, crowned by a tribuna or pavilion. The chess pieces were not distinguished by colour but instead, without a doubt, by their shape. Next to each of the two kings there is a queen. The first is inside a crenellated structure, the other is inside a pavilion. In the front row there are elephants, three chariots each with four horses, two pairs of knights, and a foot soldier or pedone or pawn, similar to what you see on the tribuna or tribune of the queen: this proves that these pieces belonged to the same game. The armour of the knights and the pawn are absolutely identical to those of the figures in the tapestry of Queen Mathilde, conserved at Bayeux: these are the Norman knights who conquered England in the mid-11th century. ${ }^{4}$

2 Ung jeu complet d'eschetz d'ivire ..., estoit à Charles Maigne: de Montesquiou-Fezenzac, Le Trésor de Saint-Denis, pp. 213-15.

3 Cet devotieux Roy et Empereur a donné ... un riche psautier escrit en lettres d'or, avec un tres beau jeu d'échaics d'ivoire, dont les personnages sont grands: Jean Doublet, Histoire de l'Abbaye de S. Denys en France (Paris 1625), p. 1213.

4 "On voit sur cette tablette plusiers pièces d'anceins jeux d'échecs, en ivoire; seize de ces pièces étaient autrefois dans le trésors de Saint-Denis. On a dit qu'elles provenaient d'un jeu d'échecs donné à Charlemagne par le calife Harun a-Rashid. Quinze de ces piéces sont moins anciennes. Au fond sont les deux rois et les deux reines. L'un des rois est dans un édifice crénelé, vétu d'habits royaux, le sceptre en main, assis sur son trône; deux valets tiennent les rideaux. L'autre rois est dans un édifice sans créneaux, terminé en tribuna [original italics] ou pavillon. On ne reconnaissait pas ancors les pièces de l'échiquier à la couleur, mais sans doute à la forme. A côté de chacun des rois, est la reine; l'und dans un edifice crénelé, l'autre dans un pavillon. Sur le devant sont trois éléphants, trois chars à quatre chevaux, deux cavaliers et un fantassin ou pion [original italics], semblable à celui qu'on voit sur la tribuna de la reine, ce qui prouve que ces piéces appartenaient au même jeu. Les armures des cavaliers et du pion sont absolument pareilles à celle des figures de la tapisserie de la reine Mathilde, conservée à Bayeux; ce sont celles des chevaliers normands qui firent la conquête de l'Angleterre, 
The pieces were distributed in two rows, with the two pairs of kings and queens in the back row and the elephants, the chariots, the two pairs of knights, and the foot soldier or pawn in the front row. The placement is more or less the same as was maintained in the vitrine at the Cabinet of Medals and Antiquities, where the set was displayed until a short time ago (Figure. 9.1). ${ }^{5}$ Du Mersan was the first to notice that the armour of two of the four knights of Charlemagne's échiquier, or chess set, is very similar to that worn by the Norman knights represented in the tapisserie from Bayeux, the large piece embroidered with scenes of the conquest of England and formerly preserved in Bayeux Cathedral. ${ }^{6}$ Based on this observation, he was also able to identify which pieces among those transferred to the Cabinet of Medals and Antiquities were part of the same chess set. ${ }^{7}$ Just short of a century later, Adolph Goldschmidt pointed out, for the first time, that the chess pieces from Saint-Denis are incredibly similar to the magnificent plaques still kept today in the Diocesan Museum of San Matteo in Salerno that depict narrative scenes from the Old and New Testaments (figures. 9.1, 9.2). ${ }^{8}$

The hypothesis that the Charlemagne chess set might have its origins in southern Italy was proposed by Goldschmidt in his detailed cataloguing of the 16 pieces as part of his large survey of ivory sculpture produced in the West. The connection between the Saint-Denis chess set and the Salerno plaques, founded on a meticulous comparative analysis of their techniques and

sous Guillaume-le-Conquérant, au milieu du XIe siècle." See: Marion du Mersan, Histoire du Cabinet des Médailles, antiques et pierres gravées, avec une notice sur la Bibliothèque Royale et une description des objets exposés dans cet établissement (Paris, 1838), pp. 25-27, esp. 25.

5 The collection housed at the Cabinet of Medals and Antiquities is being rearranged. The chess pieces have undergone careful restoration and analysis under the direction of the chief conservator of the collection, Mathilde Avisseau-Broustet. Thanks to these circumstances, in January 2019 I had the privilege of examining the game pieces during the restoration process. I am very grateful to my colleagues Mathilde Avisseau-Broustet and Azzurra Palazzo, the restorer, for this opportunity.

6 For the history of the embroidered cloth and the story of its fate between the 18th and 19th centuries, see: Xavier Barral I Altet, En souvenir du roi Guillaume. La broderie de Bayeux. Stratégies narratives et vision médiévale du monde (Paris, 2016), pp. 34-46.

7 Du Mersan itself recognized that the figure (inv. 55.307), traditionally identified as a vizir, maybe have come to the Cabinet of Medals and Antiquities of BnF as part of a collection of antiquities belonging to the count of Caylus. Indeed, the piece can be seen in an engraving published in the sixth volume of the series that describes the collection, see: Anne-ClaudePhilippe de Caylus, Recueil d'antiquités égyptiennes, étrusques, grecques, romaines et gauloises, 6 (Paris 1764), pp. 323-25, and tav. CIII. I owe my knowledge of this to Mme Mathilde Avisseau-Broustet, to whom I wish to express my thanks.

8 Adolph Goldschmidt, Die Elfenbeinskulpturen aus der Romanischen Zeit, XI.-XIII.Jahrhunderts (Berlin 1926), pp. 46-48. 
styles, was never again discussed. Even less attention was given to a note that Goldschmidt himself added in the margin of the catalogue, naming Sicily as another possible place of origin for the set: "At the moment it is not possible to establish whether these figures were made in Sicily or in a southern Italian city."9

\section{From the Kingdom in the Sun to Saint-Denis}

The circumstances around the transfer of the Charlemagne chess pieces to France are unclear. Mention of the pieces in the inventory of the abbey treasury leads us to believe that they arrived during medieval times, possible by the

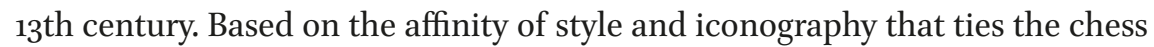
pieces to the plaques of Salerno Cathedral, Michel Pastoureau proposed that the set could have been gifted from the archbishop of Salerno to Philip the Bold on the occasion of his passage through the city. ${ }^{10}$ Another very reputable hypothesis - formulated some time ago by Danielle Gaborit-Chopin ${ }^{11}$ and recently revisited ${ }^{12}$ - instead associates the chess set with the most prestigious core of the Saint-Denis treasury, established by Abbot Suger around the middle of the 12th century. However, if the set had been a gift from the new sovereign of Sicily, Roger II, to the powerful abbot of Saint-Denis, this begs the question of why Suger did not mention it as one of the most important mirabilia of the treasure.

In my opinion, it would make more sense that the acquisition took place, as Pastoureau suggests, during the late Middle Ages, when the exotic appearance and morphological characteristics of the chess set could be more easily attributed to the time of Charlemagne and to the Islamic East. The shape and size of the pieces identify them as a decorative set of great prestige, one decidedly destined for a secular context, such as a palace or castle. If the pieces

9 “... Ob die Figuren aber in Sizilien oder einer süditalienischen Stadt gearbeitet, läßt sich einstweilen nicht bestimmen."

10 Michel Pastoureau, L'Échiquier de Charlemagne. Un jeu pour ne pas jouer (Paris, 1990), pp. 34-36. Reissued with some additions, in: Michel Pastoureau, "Larrivo degli scacchi in Occidente. Storia di una acculturazione difficile," in Michel Pastoureau, Medioevo simbolico (Paris 2004; repr. Rome, 2005), pp. 247-68.

11 For this most recent hypothesis, see: Danielle Gaborit-Chopin, "Échecs de Charlemagne," in Le trésor de Saint-Denis. Musée du Louvre, Paris, 12 mars-17 juin 1991 (Paris, 1991), pp. $132-41$.

12 More recently: Philippe Cordez, "O joco de xadrez: imagem, poder e igreja (fin do século X - início do século XII)," Revista de História 165 (2011), 93-120, esp. 104-14. 
came to Saint-Denis through Philip the Bold, they could have been a gift from his uncle Charles of Anjou; the latter may have offered his nephew, who had passed through Sicily during his return from the Holy Land, one of the furnishings of the palaces of Palermo. The historical attribution of these chess pieces to Charlemagne could perhaps hide this Sicilian origin. ${ }^{13}$ It is known that the Angevin ruler used part of the spoils resulting from the conquest of the Regnum for diplomatic purposes. A few decades later, one of the thrones of Frederick II appears in the inventories of the treasury of the Holy See. ${ }^{14}$ The pieces from Charlemagne's set may have found a similar fate..$^{15}$

The foremost similarity among the Salerno plaques, the Charlemagne chess set, and other comparable pieces attributable to the ateliers of the Amalfi Coast is their material: rare and costly elephant ivory. During the middle centuries of the medieval era, elephant ivory was a very difficult material to obtain and was therefore very highly valued in Europe as well as the Near East. The difficulty in procuring ivory compromised its availability even in Byzantium, which remained one of the main centres for the creation of carved ivories in the entire Mediterranean. ${ }^{16}$ By considering these historical circumstances,

13 Lucinia Speciale, "Il gioco dei Re. Intorno agli 'Scacchi di Carlo Magno,'” in Medioevo: la Chiesa e il Palazzo. Atti del Convegno internazionale di studi, Parma, 20-24 settembre 2005, ed. Arturo C. Quintavalle (I Convegni di Parma) 8 (Parma, 2007), pp. 238-48, esp. 245-46.

14 For the scattering of the treasures of Frederick II, more recently: Hermann Fillitz, "Tesoro imperiale," in Federico II. Enciclopedia Fridericiana 2 (Roma, 2006), pp. 824-29.

15 I have already argued in favour of this hypothesis, which I still find convincing, in: Lucinia Speciale, "Ludus scachorum: il gioco dei re. Forma e iconografia degli scacchi tra l'Italia e l'Europa," in L'Enigma degli avori medievali da Amalfi a Salerno, ed. Ferdinando Bologna, 2 vols (Napoli, 2008), 1:203-29.

16 For an overview, see: Anthony Cutler, The Craft of Ivory. Sources, Techniques and Uses in the Mediterranean World: A.D. 200-1200 (Washington, D.C., 1985); Anthony Cutler, The Hand of the Master. Craftmanship, Ivory and Society in Byzantium (gth-IIth Centuries) (Princeton, 1994). See also the introductory pages of the catalogue: Ivoires: de l'Orient ancien aux temps modernes, eds. Annie Caubet, and Danielle Gaborit-Chopin (Paris, 2004), pp. 28-3o. For a recent synthesis regarding the Salerno corpus, see: Sarah M. Guérin, "The tusk: origins of the raw material for the Salerno ivories," in The Salerno Ivories: objects, histories, contexts, eds. Francesca Dell'Acqua, Anthony Cutler, Herbert L. Kessler, Avinoam Shalem, and Gerhard Wolf (Berlin, 2016), pp. 21-29. This last entry leaves me perplexed about the hypothesis that the entire corpus of the Salerno plaques could have been made from only one tusk: in their current state it is impossible to evaluate exactly how much of the Salerno set has gone missing. In regards to this, see: Anthony Cutler, "The fabric, facture 
we get a sense of the exceptional magnificence of this game set, which is still impressive today despite the fact that only about half of the original set survives. According to the description in the inventory, the Charlemagne chess set was comprised of 32 pieces and a large chessboard measuring about one square metre and also made of pure ivory. Preserved today are 15 of the major pieces and only one of the minor pieces: two kings, two queens, four elephants (bishops), four knights, three chariots (towers), and only one pawn. It is an exceptional corpus, both in quantity and scale. The most important pieces, the two kings (figures. 9.1, 9.3), are more than $15 \mathrm{~cm}$ tall. The chessboard and virtually all the minor pieces are missing.

The type of architecture that houses the two royal couples is reminiscent of the style of the Salerno plaques; the domes, the slender shape, and the raised arches of the two porticos recall the oriental shapes that distinguished the architecture of the Amalfi Coast between the 11th and 12th centuries. The stylistic resemblance that links the Parisian pieces to the Salerno group is very evident. In the rigid in-the-round figurines of the Saint-Denis set, we see the ample robes marked by double lines and the big eyes that characterize the Salerno images (figures. 9.2, 9.3). Very similar characteristics can be recognized above all in one of the two artists to whom the scenes of the New Testament can likely be attributed. ${ }^{17}$

The original destination and date of the Salerno ivories is still today very controversial. ${ }^{18}$ In my opinion, despite the similarity of their decorative motifs to the frames of the ivories at the entry to Salerno Cathedral (mutually considered to be from 1085), ${ }^{19}$ the smooth relief shapes of the ivory plaques seem to

and enduring enigma of the Salerno ivories," in The Salerno Ivories, ed. Dell'Acqua et al., pp. 11-19.

17 Ferdinando Bologna, Opere d'arte nel Salernitano dal XII al XVIII secolo (Napoli, 1955), pp. 11-19; see also Robert Bergman, The Salerno Ivories. Ars Sacra from Medieval Amalfi (Cambridge, Eng., 1980), pp. 76-87; Antonio Braca, Gli avorimedievalidel Museo Diocesano di Salerno (Salerno, 1994), pp. 193-205.

18 For a balanced evaluation of the studies following the Salerno exhibit of 2007, see: Paul Williamson, "Review of Valentino Pace, Una Bibbia in avorio: Arte mediterranea nella Salerno dell'XI secolo (Milano, 2016)," The Burlington Magazine 169 (2017), p. 556.

19 Francesco Gandolfo, La scultura normanno-sveva in Campania. Botteghe e modelli, (Fonti e studi) 9 (Roma, 1999) p. 24. More recently: Antonio Braca, Il Duomo di Salerno. Architetture e culture artistiche del medioevo e dell'Età Moderna (Società Salernitana di Storia Patria, Collana di Studi Storici Salernitani) 19 (Salerno, 2003), pp. 79-93; Valentino Pace, "La cattedrale di Salerno. Committenza, programma e valenze ideologiche di un monumento di fine XI secolo nell'Italia meridionale," in Valentino Pace, Arte medievale in Italia meridionale 1. La Campania, (Nuovo Medioevo) 70 (Napoli, 2007), pp. 69-9o. (Updated version of the paper of the same title originally published in: Desiderio di Montecassino e l'Arte della Riforma Gregoriana, ed. Faustino Avagliano (Montecassino, 1997), pp. 189-230). 
belong to a later stylistic phase, attributable to at least the early 12th century. A stylistic comparison of the Salerno ivories to other important carved-ivory artifacts produced in the workshops of the Amalfi Coast during this period also justifies attributing them to a later time. I am referring to the ivory casket of the abbey of Farfa, a work of art which for historical reasons could not have been made after 1072 (Figure. 9.4). ${ }^{20}$ That the Farfa casket predates the Salerno ivories is demonstrated by the much more rigid and awkward shapes of the figures on the former. In terms of style, the Charlemagne pieces seem to mark a transition between the Farfa casket and the Salerno ivories. This is easy to see by comparing one of the two Saint-Denis queens (Figure. 9.5; BnF inv. 55.310) with the Visitation scene carved on the lid of the Farfa casket (Figure. 9.4). The general structure of the latter composition, the relationship between the figures and the architecture, and even the handmaid pulling back the curtain in the scene where the Virgin Mary is hugging Elisabeth all find evident parallels in the chess piece. ${ }^{21}$ The treatment of the robes, marked by two vertical lines, is another shared feature.

The stylistically intermediate position that the Charlemagne set occupies with respect to the other two works of art offers a clue towards resolving, in a chronological sense, the differences between the Farfa casket and the Salerno ivories. Less probable, in my opinion, is the hypothesis that two different carving traditions developed, in parallel yet independently, between the 11th and 12th centuries in such a relatively limited geographic area as the Amalfi Coast. ${ }^{22}$ The unity of the school is demonstrated by the kinship that binds the Charlemagne chess set to both the Cassetta di Farfa and the Salerno plaques.

$20 \quad$ For the Farfa casket, see: Pietro Toesca, "Un cimelio amalfitano," Bollettino d'arte 27 (1933-34), 537-43; Robert Bergman, “A School of Romanesque Ivory Carving in Amalfi," Metropolitan Museum Journal 9 (1974), 163-86, esp. 164-71; Antonio Braca, "Lavori in avorio in Amalfi medievale: considerazioni e ipotesi," Rassegna del Centro di Cultura e Storia amalfitana n.s. 3 (1993), 111-28; Antonio Braca, "Intorno alla cassetta di avorio di Farfa. Il cimelio, il donatore e la cassetta amalfitana," in L'Enigma, ed. Bologna, 1:161-201. For a status quaestionis now, see: Giuseppe Perta, "La 'Cassetta di Farfa' e l'itinerario mediterraneo dei de comite Maurone," Annali della Pontificia Insigne Accademia di Belle Arti e Lettere dei Virtuosi al Pantheon 16 (2016), 373-92.

21 Lucinia Speciale, “Guerra e Pace. Ancora sugli 'Scacchi di Carlo Magno," in Tempi e forme dell'arte. Miscellanea di studi offerti a Pina Belli D'Elia, eds. Luisa Derosa, and Clara Gelao (Foggia, 2011), pp. 73-81, esp. 77. More recently: Lucinia Speciale, "Il gioco di un re: gli Scacchi Di Carlo Magno," in Castrum Superius. Il Palazzo dei re normannni (Palermo. Fondazione Federico II) (Palermo, 2019), pp. 204-15.

22 See: Ferdinando Bologna, "Avori medioevali da Amalfi a Salerno, senza enigmi," in L'Enigma, ed. Bologna, 1:21-97. 
In the Parisian set, the geometric motif in relief that characterizes the top of the four principal figures reminds us of another artifact, traditionally linked to the corpus of southern Italian ivories, namely the oliphant (Figure. 9.6; inv. CL 13.065) from the treasury of Saint-Arnould Abbey in Metz, now preserved at the Cluny Museum in Paris. ${ }^{23}$ The piece is considered to be one of the oldest in the corpus of carved-ivory horns found among the many ecclesiastic treasuries in continental Europe after the year 100o. According to a very convincing hypothesis, the Metz oliphant may have been made in Egypt and then brought to the West, where it was then reworked most likely for use as a reliquary. Supporting this theory is the decidedly religious nature of the iconographic subject matters that were added at a later time: the Ascension of Christ and busts of the apostles. ${ }^{24}$ The oliphant of Metz shows similarities to the Charlemagne chess set in terms of a certain coarseness in the carving of the new reliefs and, above all, in the ornamental motifs added in the second phase. For instance, the lozenged-shaped rosettes at the top of the two king-pieces and those present in the decorative band topping the Ascension scene are quite similar (figures. $9.3,9.6)$.

Unfortunately, the medieval history of the oliphant in the Cluny Museum does not offer any indication of where the artifact travelled before arriving in Metz. There are convincing arguments that the reworking of the original Egyptian piece may have been executed in the Amalfi Coast workshops, but this remains conjecture. ${ }^{25}$

23 For the piece of art, see: David Ebitz, "Secular to sacred: the transformation of an oliphant in the Musée de Cluny," Gesta 25 (1986), 31-38, n. 23. For an overall view of the phenomenon, see:Valentino Pace, "Maniera saracena in Italia meridionale:l'olifante Basilewsky," Palazzo Madama. Studi e notizie 4-3 (2014-15), 66-73.

24 In fact, the oliphant of Metz is an interesting manifestation of a phenomenon that Avinoam Shalem has happily defined as 'Islam Christianized': Avinoam Shalem, Islam Christianized. Islamic Portable Objects in the Medieval Church Treasuries of the Latin West (Ars Faciendi, Beiträge und Studien zur Kunstgeschichte) 7, 2nd ed. (Frankfurt, 1998).

25 The piece was received at Cluny after the Spitzer Collection was dispersed. For its history and the correct reference to its southern Italian context, see: Danielle Gaborit-Chopin, Ivoires médiévaux, Ve-XVe siècle. Musée du Louvre, Département des Objets d'Art. Catalogue (Paris, 2003), pp. 205-06; Avinoam Shalem, The Oliphant. Islamic objects in Historical Context (Leiden, 2004), pp. 109-10. More recently: Lucinia Speciale, "86. olifante," in L'Enigma, ed. Bologna, 2:470-73. I had the extraordinary opportunity to study the Cluny oliphant up close during its display at the Salerno exhibit of 2007. During a study session of the scientific committee held there, I was able to see it next to the Farfa casket and to observe the stylistic affinity that ties these two works together. I am very grateful to Ferdinando Bologna for including me in the scientific committee concerning L'Enigma degli avorimedievali da Amalfi a Salerno and for entrusting me with the section dedicated to the chess pieces and the oliphants. 
Taking a closer look at the Charlemagne chess set, or at least at what remains of it, we see the work of two artists whose different personalities most likely account for the variances in carving among the pieces. This is evident in the small differences that characterize the two pairs of elephants, mounted by teams of two to three mahout figures each (figures. 9.1). Since the identity of each of the four pieces is the same, the contrasting aspects of the carving are what reveals the hands of two different artists. Differences can be observed in the quality of the relief, perceptible above all in the tiniest and liveliest details of the characters placed on the backs of the animals. One of the two pairs, the one with only two mahouts (figures. 9.1, 9.7), has a distinctive feature probably tied to the placement of the pieces on the chessboard: the elephants' trunks are folded, in one case towards the right and, in the other case, towards the left. This solution allows for differentiation of two otherwise identical elements of the pieces, both having the same harness for war, the same clothing, the same equipment. This particularity probably suggests the respective positions of the two elephants, to the right or to the left of the command pair. The two elephants surmounted by three mahouts each are likewise differentiated from one another ${ }^{26}$ - in this case, by their saddlecloths, one patterned with a lozenge motif containing a circle and the other with alternating bands of circles (Figure. 9.1).

Rather than indicating that the pieces belong to different game sets, ${ }^{27}$ these small discrepancies in decoration respond to a need to distinguish the opponents' pieces from one another even while working in the same material for both. This same need explains the choice to paint the two halves of the set red and gold, respectively; this paint was still evident on the pieces at the beginning of the 2oth century but has by now almost entirely vanished. ${ }^{28}$ During the medieval period, the standard colour distinction was not as it is today - in black and white, which was adopted only from the 14th century - but in red and white. ${ }^{29}$

26 As a result of an accident at an unknown time, one of the two elephants in this pair is missing its central mahout, of which only his legs remain (inv. 55.315).

27 This is the opinion of: Michel Pastoureau, Pièces d'Échecs. Bibliothèque Nationale. Cabinet des médailles et antiques, 7 juin-3o septembre 1990 (Paris, 199o), p. 16.

28 Goldschmidt, Elfenbeinskulpturen, p. 46. The analysis carried out between the end of 2018 and 2019 aimed to safely determine the presence of these traces.

29 See: Alessandro Sanvito, "Bianco e nero o rosso e verde?," L'Italia scacchistica 943 (1984), $143-46$. 
The distribution of labour between the two artists and the small differences revealed by close observation of the figures leave us to suspect that the creator of the set did not work from a model and that certain choices were made over the course of creating the pieces. This leads us to believe that the Charlemagne set should be considered a unicum. The dimensions of the set are undoubtedly exceptional, such that it can be seen as a sort of table monument, the larger pieces of which exceed the dimensions of any other medieval artifact of its kind.

The pieces of the Saint-Denis set reveal a technical expertise and a formal air of sculpture in the round, far from the precious graphic style of the Salerno plaques. Carving of this nature requires an ample availability of the raw material and great technical mastery. Indeed, the principal figures of the game set were carved from large blocks of ivory, produced through careful sectioning of an elephant tusk. That each piece was carved from a half-tusk block is particularly evident in the kings and queens, each presented within an edifice whose semi-circular base follows the external curve of the original block (figures. 9.1). ${ }^{30}$ A technically similar solution, skilfully utilizing the original profile of the tusk, was employed in an isolated king-piece conserved in the Louvre collection (Louvre, Oa inv. 6o62). This is a particularly interesting piece that combines the aniconic shape of Islamic game pieces with a bas-relief scene of the donning of arms. ${ }^{31}$

30 A close examination of the entire set, which I was able to perform some time ago, confirmed this opinion for me. The publication of the restoration will offer a hypothesis on the eborarii's work techniques used in the Échiquier of Saint-Denis, starting with the sectioning of the tusks. A study of the set's material gives us at least one certain piece of information: the two queens are made of two halves of one block of ivory. The piece inv. 55.309, which appears smaller in size and of lesser workmanship than its twin, was however carved from the same block of tusk. The differences we see between the two pieces do not mean they were made at different times, as I had previously thought (Speciale, "Ludus scachorum," p. 208), but instead depend on other causes. This reconsideration comes from a precious exchange of views with Azzurra Palazzo, who was entrusted with the restoration of the Charlemagne set.

31 For this last one, see: Lucinia Speciale, "84. Re (pezzo per il gioco degli scacchi)," in L'Enigma, ed. Bologna, 2:464-65 (with references); Isabelle Bardiès-Fronty, "101. Pièce d'échecs: roi," in Art du jeu, jeu dans l'art. De Babylone à l'Occident médiéval. Musée de Cluny - Musée national du Moyen Âge, 28 novembre 2012-4 mars 2013 (Paris, 2012), p. 108. 
From a purely iconographical point of view, the figures of the Parisian set reveal a distinctly eastern influence. The ludus scachorum (the game of the kings) almost certainly began in India ${ }^{32}$ and expanded rapidly across Persia to the Near East, where it became widespread between the 6 th and 7 th centuries thanks to the Arabs. The game preserved its connotations as a simulation of strategic warfare even in the hands of the Arabs, through whom the game eventually came to the Latin West. The fact that the game spread through Europe via the Arabs, and not via Byzantine intermediation, is demonstrated by the Arabic names of the figurines that then resurface in the different Romance traditions of Western Europe. The names of the pieces and the rules of the game that are still in use today in the Latin or Germanic languages reflect this linguistic matrix of terms, recalling their phonetic roots through assonance, starting with the name of the game: chess, échecs, scacchi, Schachspiel are all independently derived from the Arabic transliteration of the Persian word shah, or king. In the version of the game that the Arabs played, each of the two players had a series of pieces consisting of two governing figures, the king and his prime minister (which in Arabic is vizir), plus the four components of an eastern army: the infantry or foot soldiers, those on horseback, the chariots, and the elephants. As the game became affected by transpositional changes between the 11th and 12th century in the Latin West, the military connotations that had governed it were reinterpreted in socio-allegoric terms. In Christian Europe, the chess pyramid quickly became a great metaphor for the feudal order. ${ }^{33}$ The abstract geometry of a war-game became converted into a lighter drama of court life. Indeed, the game's popularity, particularly among the aristocratic elites, coincided with the height of the ideology of chivalry.

32 A wonderful profile of the history of the game is that given by: Harold J. R. Murray, History of Chess (Oxford, 1913, repr. New York, 1965). Murray's monograph remains the most complete work on the history of the game, beginning with its origins. More recent: Richard Eales, "The Game of Chess: an Aspect of Medieval Knightly Culture," in The Ideals and Practice of Medieval Knighthood (Woodbridge, 1986), pp. 12-34; Rainer A. Müller, "Il gioco degli scacchi come metafora della civiltà medievale," Ludica 1 (1995), 114-25; Pastoureau, L'arrivo, pp. 247-68; Sophie Makariou, "Le jeu d'échecs, une pratique de l'aristocratie entre Islam et chrétienté des IXe-XIIIe siècles," in Chrétiens et musulmans autour de l'an 110o. Actes des 36 e Journées Romanes de Cuxa, Les cahiers de Saint-Michel de Cuxa 35 (2003/04), 127-40.

33 Pastoureau, L'arrivo; Müller, Il gioco; Chiara Frugoni, "Das Schachspiel in der Welt des Jacobus de Cessolis," in Das Schachbuch des Jacobus de Cessolis. Codex Palatinus Latinus 961, (Codices e Vaticanis Selecti) 74 (Zurich, 1988), pp. 35-77. 
We find the reverberations of this change in the shifting identities of the key figures of the game. First was the vizir who was transformed into a female figure, the queen, as first documented around the end of the 1oth century in the Versus de scachis, a composition in verse that preserves the oldest transcription of the figures and rules of the game in the Latin language. ${ }^{34}$

This historical context, alongside more pointed stylistic reasons, calls into question the identification and dating of a chess piece ${ }^{35}$ in the collection of the Cabinet of Medals and Antiquities (BnF inv. 55.307) ) $^{36}$ as well as insistent attempts to associate it with the Charlemagne set. The figure is generally identified as a vizir and dated to the late 11 th century. ${ }^{37} \mathrm{In}$ fact, it is a unicum, which cannot be paralleled with any traditional western chess figures. ${ }^{38}$ One of the most significant changes in the pieces was the transformation of the elephant, whose name in Arabic is Al-fil (Figure. 9.7). In the western version of the game, the piece kept its Islamic position and way of moving on the board, but its identity changed greatly, sometimes becoming a bishop or even the diametrical opposite, a jester $(f o u) \cdot{ }^{39}$ In another case, that of the tower or rook, the change from an Islamic to a western figure seems to have resulted from a simple phonetic assonance: from the Arabic rukh the Latin rochus, for chariot, and the Romance-language roque and rocca. The aniconic character of the Arab

For the origin and date of this composition, see: Helena M. Gamer, "The Earliest Evidence of Chess in western literature: the Einsiedeln Verses," Speculum 29 (1954) 734-50.

The recent opportunity I had to examine this piece in Paris at the studio of Mathilde Avisseau-Broustet reinforces my conviction. I do not know the results of the analysis carried out while the piece was being restored but the quality of the engraving is indisputably very different from that of the Charlemagne set.

36 Du Mersan, Histoire du Cabinet, p. 26.

37 Goldschmidt, Elfenbeinskulpturen, p. 47, tav. LXI; Pastoureau, Échiquier, p. 44.

38 See: de Caylus, Recueil d'antiquités égyptiennes, pp. 323-25, and tav. CIII. Its documented presence in the Caylus Collection moves the date of its making earlier but does not demonstrate medieval origins. In my opinion, this is a rather interesting case of antiquarian reinterpretation, which started from an archetype whose original function was no longer intended, as revealed by the Caylus catalogue itself. Concerning the production of this curious piece, I would point to: The king-pieces inv. 6o C and inv. $61 \mathrm{C}$ now in the Museo del Bargello, formerly in the Collezione Carrand. See also: Speciale "Ludus scachorum," p. 215; Lucinia Speciale, "Il gioco come status-symbol. Gli scacchi tra formule rappresentative e testimonianze materiali," in Il gioco nella società e nella cultura dell'altomedioevo, Spoleto, 20-26 aprile 2017, Settimane di Studio della Fondazione Centro Italiano di Studi sull'Alto Medioevo 65 (Spoleto, 2018), pp. 241-53, esp. 26o-61. For the latter see: Danielle Gaborit-Chopin, "Pedine e scacchi," in Gli avori del Museo Nazionale del Bargello, ed. Ilaria Ciseri (Milano, 2018), pp. 153-70, esp. 162-66. Gaborit-Chopin believes the pieces are medieval. 
pieces, which spread in the West together with the knowledge of the game starting from the second half of the 1oth century, lent itself to the allegorical reinterpretation of the pieces. In the middle centuries of the Middle Ages, completely figurative versions of the game seem to have only been made in the West. The Charlemagne chess set is situated at a very primitive stage in this metamorphosis. The only piece in the set affected by western types is the queen; by contrast, the chariots and the elephants preserve the very pointed military-strategy aspect of the game. This shows that the design and execution of the pieces took place geographically in an environment that was heavily permeated by Islamic culture, just as southern Italy was, beginning in the High Middle Ages.

In the Parisian set, both the elephants' harnesses and the elephants themselves reflect a non-episodic knowledge of Islamic artifacts that finds parallels in southern Italian Romanesque sculpture. ${ }^{40}$ The decorative motif of the dossal of Montevergine's wood throne is a particularly significant comparison in this regard. ${ }^{41}$ Although the Montevergine relief is probably from a later

40 We can see the connection with the pair of elephants that supports the bishop's chair made by Romualdo for the Canosa Cathedral in the second half of the 11th century. For historical-critical context, see: Silvia Silvestro, "La Puglia," in La scultura d'età normanna tra Inghilterra e Terrasanta. Questioni storiografiche, ed. Mario D'Onofrio (Fonti e Studi) 11 (Roma, 2001), pp. 105-38, esp. 113-16.

41 For the Montevergine Cathedral, see: André Grabar, "Thrônes épiscopaux du XIe et XIIe siècles en Italie méridionale," Wallraf-Richartz-Jahrbuch 16 (1954), 7-52, esp. 34-36 (where the exquisite profane symbology of the decoration was first noted). Also: Antonella Putaturo Murano, "Arredi lignei," in Insediamenti verginiani in Irpinia. Il Goleto, Montevergine, Loreto, ed. Vincenzo Pacelli (Cava dei Tirreni, 1988), pp. 185-87. And more recently: Valentino Pace, "La Campania," in La scultura d'età normanna tra Inghilterra e Terrasanta. Questioni storiografiche, ed. Mario D'Onofrio (Fonti e Studi) 11 (Roma 2001), pp. 71-104, esp. 92, 103. Lastly: Gaetano Curzi, Arredi lignei medievali. L'Abruzzo e l'Italia centromeridionale. Secoli XII-XIII (Cinisello Balsamo, 2007), pp. 86-95. The chronology of the work and its original destination are still uncertain. The piece has aroused the most imaginative hypotheses, among them a possible attribution to Frederick II, see: Lello Capaldo, "Il Trono di Federico II," in Atti dell'Accademia Pontaniana n.s. 47 (1998), 73-9o. In my opinion, the decidedly profane character and the decorative repertoire of its reliefs suggest that the throne was made for a secular destination. Since the privilege of administering justice in the fiefdom of Mercogliano was conferred on the abbots of Montevergine between 1170 and 1195, the same time -frame generally indicated as terminus ad quem for for the artifact's production, perhaps this arc of time should rather be taken as a terminus ante quem. As previously mentioned, the abbots of Montevergine, together with the county, acquired the governing rights as lords over the fiefdom. The throne may have been made for the count of Mercogliano's residence and transferred to the abbey only after the family died out. The changes made to the piece of furniture - originally one seat, then three - may be explained by the need to adapt the furnishings to their new functions as part of the abbey pulpit. Some of the many questions that remain unanswered regarding 
period, the parallel is particularly fitting in terms of iconography and in the secular subject represented in the relief, possibly an imitation of a fabric. The profile of an elephant in military dress mounted by a howdah full of people is also seen in one of the rotae in a sculpted panel of Aversa Cathedral ${ }^{42}$ and in a velum painted in the apse of Santa Maria a Foro Claudio near Ventaroli. ${ }^{43}$ Motifs of this sort must have been well distributed throughout the Campania region during the 11th century, as evidenced by the memory of a pallium magnum cum elefantis present among the vestments offered by Empress Agnese del Poitou to the abbey of Montecassino on the occasion of her visit in $1071 .^{44}$ Another example to consider from the Apulia region is the 12th-century image carved on one of the doorframes of the church of San Giovanni al Sepolcro in Brindisi, ${ }^{45}$ where one of the three mahouts that guide the elephant is seated on the animal's neck, the same configuration as in two of the Parisian chess pieces (Figure. 9.7). Another is a figure - unfortunately very damaged - of the muqarnas of the Palatina.

The Charlemagne set offers yet another important example of how the Islamic game was received in the Latin West, namely in the contrasts among the armament of the four knights. In the first pair, the figurines display pointed helmets and Norman-style almond-shaped shields (Figure. 9.1), ${ }^{46}$ analogous

the origin of the piece could be resolved by conducting a dendrochronological analysis of the materials of the throne.

42 For this see: Gandolfo, Scultura, fig. 27.

43 For the paintings of Ventaroli: Cinzia Celentano, "Schede 166a, 166b-c," in Caserta e la sua Reggia: Il Museo dell'Opera e del territorio (Napoli, 1995), pp. 210-12 (where the dating of the works is proposed again to be before the end of the 11th century, as already considered by Bertaux). For the more correct dating to the 13th century, see: Valentino Pace, in Mario D'Onofrio, Valentino Pace, La Campania, Italia romanica 4 (Milano, 1981), pp. 110-12; Valentino Pace, "Le pertinenze bizantine degli affreschi campani di Santa Maria di Foroclaudio," in Valentino Pace, Arte medievale in Italia meridionale 1. Campania, (Nuovo medioevo) 70 (Napoli, 2006), pp. 117-21 (updated version of the paper with the same title published originally in Storia dell'arte 34 (1978), 207-09); Lucinia Speciale, "S. Maria de episcopio a Ventaroli: le pitture murali più antiche," in Studi in onore di Giovanni Carbonara (in press).

44 See: Die Chronik von Montecassino, ed. Hartmut Hoffmann, MGH Scriptores 34 (1980), Chronica monasterii casinensis, 3, 31, p. 403. Regarding this, see: Pace, Campania, p. 103.

45 Umberto Scerrato, "Arte," in Gli arabi in Italia, ed. Francesco Gabrieli and Umberto Scerrato (Milan, 1979), pp. 275-574, fig. 349.

46 For the exquisitely 'Norman' connotation of this defensive element by well-known military historians of the Middle Ages, see at least: David C. Nicolle, Arms and armour of the Crusading Era: 1050-1350, 2 vols (New York, 1988), 1:506-07; Giovanni Amatuccio, “'Fino alle mura di Babilonia'. Aspetti militari della conquista normanna del Sud," Rassegna storica Salernitana 30 (1998), 7-49. 
to those seen for the first time in the Bayeux Tapestry. ${ }^{47}$ The round shield, the flat helmet, and the heavy bandage that protects the heads of the other two mounted warriors (Figure. 9.1) are instead typologically very similar to those of the Saracen knights in the muqarnas of the Palatine Chapel, who are shown contending with western-equipped characters in tournaments. ${ }^{48}$ Other characters very similar to the two knights of the Saint-Denis chess set are the sarakénoi, seen in military garb in the pages of a Greek codex produced by the chancery of Roger II around 1140. I refer to the illustrated copy of the Byzantine Universal Chronicle of John Skylitzes (Madrid, National Library, Ms. Vitr. 26-2, fol. 113v), commonly known as Skylitzes Matritensis. ${ }^{49}$

\section{$5 \quad$ Rulership and Image}

The two royal couples in the chess set show the influence of iconographic forms and symbols of power that dominated the cultural landscape of Norman southern Italy. In the four principal game pieces we see compositions that combine a Carolingian-Ottonian matrix with contemporary Byzantine elements. The sovereigns on their thrones are placed inside an arch, with curtains held open by a pair of handmaids or servants (figures. 9.1, 9.3, 9.5, 9.9). The pattern reflects traditional images widespread in southern Italy, such as those

47 Pastoureau, Pièces d'échecs, p. 28, but earlier: Gaborit-Chopin, Ivoires, p. 125. Also Braca, Gli avori, p. 138. The comparison of the drop shields of the knights of the Dionisian chess set with those of the Norman warriors of the Bayeux Tapestry accompanies the set already in du Mersan's first erudite first study, see: Du Mersan, Histoire du Cabinet des Médailles, pp. 25-27. For the fate of the Bayeux Tapestry between the 18th and 19th centuries, see now: Barral I Altet, En souvenir du roi Guillaume, pp. 34-46.

48 Speciale, Il gioco dei Re; Speciale, "Ludus scachorum," pp. 203-29.

49 For the connection, see: Lucinia Speciale, "Gli 'Scacchi di Carlo Magno' e non solo," in The "Amalfi" - "Salerno" Ivories and the Medieval Mediterranean. A Notebook from the Workshop Convened in Amalf, December 10-13, 2009, eds. Francesca Dell'Acqua, Herbert L. Kessler, Avinoam Shalem, and Gerhard Wolf (Amalfi, 2011), pp. 101-04; Speciale, "Guerra e Pace," pp. 73-82. For the origin and the date of the manuscript, see: Ihor Ševčenko, "The Madrid manuscript of the chronicle of Skylitzes in the light of its new dating," in Byzanz und der Westen. Studien zur Kunst des europäischen Mittelalters, ed. Irmgard Hutter, (Österreichische Akademie der Wissenschaften / Philosophisch-Historische Klasse) 432 (Wien, 1984), pp. 117-30; Vasiliki Tsamakda, The illustrated chronicle of Ioannes Skylitzes in Madrid (Leiden, 2002); Elena N. Boek, "The politics of visualizing an imperial demise: transforming a Byzantine chronicle into a Sicilian visual narrative," Word \& image 25 (2009), 243-57. For who possibly commissioned the codex, see: Santo Lucà, "Dalle collezioni manoscritte di Spagna: libri originari o provenienti dall'Italia greca medievale," Rivista di studi bizantini e neoellenici 44 (2007), 39-96, esp. 79-81. 
in the Exultet Rolls. The long robe, the flowing beard, and the crown of the two kings find close similarities to the Imperator of the final commemoration of the Exultet Barberini (Rome, Vatican City, Biblioteca Apostolica Vaticana, Barb. lat. 592, fol. 5), produced by the scriptorium of Montecassino Abbey around $1087 \cdot{ }^{50}$ Meanwhile, the long tunic with large butterfly sleeves, worn by the two queen-pieces of the Charlemagne set, can be easily connected to the empress and the ducissa in the Beneventan Exultet Roll of Pisa (Pisa, Diocesan Museum Exultet 2). ${ }^{51}$

The visual repertoire of the painting on parchment may not have been the only model for this iconographic element, which can also be seen as a manifestation of Herrschaftsymbolik. The aedicula that houses the sovereign evokes a prototype rooted in the figurative art of the Latin West and very well documented in the illuminated manuscripts; however, at the top of the structure that houses one of the two queens, there is a small element that may reveal an iconographic source taken from carved ivories. I am referring to the only figure that remains of the original pair of foot soldiers on top of the building (Figure. 9.9). The position and function corresponds to that of the two imperial eagles in the portrait of an empress, perhaps Ariadne (before 457-515) in the late antique ivory plaque now preserved in the collections of the Kunsthistorisches Museum in Vienna (Vienna, Kunsthistorisches Museum, Antikensammlungen, inv. X, 39) ${ }^{52}$ In the ivory relief depicting the enthroned sovereign, who wears a jewelled crown and holds the orb and cross, once again we find the parted curtains and even the similar spindle motif that adorns the edges of the architectural elements of the game piece. The inventor of the Charlemagne set, and its artists, undertaking the sophisticated task of transposing the ludus scachorum

$5^{\circ} \quad$ For the origin and date of the Exultet Roll, see: Lucinia Speciale, Montecassino e la Riforma Gregoriana. L'Exultet Barb. lat. 592, (Studi di arte medievale) 3 (Rome, 1991), pp. 119-46, esp. 65-67; Lucinia Speciale, Immagini per la storia. Ideologia e rappresentazione del potere nel mezzogiorno medievale, (Fondazione 'Centro Internazionale di Studi sull'alto medioevo', Testi, studi, strumenti) 30 (Spoleto, 2014), pp. 37-74.

51 For a classification of the Exultet Roll, in my opinion attributable to the early 12th century in Puglia, see most recently: Lucinia Speciale, "Il libro decorato nella Puglia dell'alto medioevo. Qualche novità e qualche riflessione," in Bizantini, Longobardi e Arabi in Puglia nell'alto medioevo, Ventesimo Congresso internazionale di studio del Centro Italiano di studi sull'alto medioevo, Savelletri di Fasano (BR), 3-6 novembre 2011 (Spoleto, 2012), pp. 685-706, esp. 701-02; Speciale, Immagini per la storia, pp. 103-09 (with further references).

52 For the artwork, most recently, see: Diliana Angelova, "The Ivories of Ariadne and Ideas about Female Imperial Authority in Rome and Early Byzantium," Gesta 43/1 (2004), 1-15 (with references). 
from an aniconic into a figural series, may have looked to an iconographic model very similar to the imperial diptych. ${ }^{53}$

The availability and selection of a late antique ivory in 12th-century Sicily necessarily gives a clue as to the original destination for and patron of the Charlemagne chess set. The history of the plaque with the portrait of the empress has not been entirely deciphered. ${ }^{54}$ However, during the Middle Ages such diptychs were carefully hoarded, not only for the often extraordinary quality of their carving but probably also for their refined symbolism of power. ${ }^{55}$ Something to take into consideration in exploring how the Saint-Denis pieces fit with this model is the ideological atmosphere of Roger II's Palermo, the capital of a region that he transformed from a territorial fiefdom into a kingdom. In this light, the position and identity of the two crouching animals on the back of the tribune hosting the queen assume particular significance (Figure. 9.10). In the past, the relatively mediocre state of conservation of this piece

53 The Vienna panel comes from the Riccardi Collection in Florence, the same to which another portrait of an empress has long been attributed, currently in the Bargello: see Inventario e stima della libreria Riccardi. Manoscritti e edizioni del XV secolo (Firenze 1810), p. XVII. For a history of the collection: Giuseppe De Juliis, "Le vicende degli antichi avori della collezione Riccardi." Commentari n.s. 29 (1978), 144-56; Roberto Cassanelli, "I modi della trasmissione. Dai tesori altomedievali ai musei d'arti applicate," in Eburnea Dyptica. I dittici d'avorio tra Antichità e Medioevo, ed. Massimiliano David (Bari, 2007), pp. 317-29. The oldest circumstances concerning the conservation of the two panels are unfortunately unknown. For a complete overview: Danielle Gaborit-Chopin, "Placca centrale di un Pentittico con imperatrice (Ariadne)," in Gli avori, ed. Ciseri, pp. 51-54.

54 Fundamental for a general overview of the subject is: Richard Delbrück, Die Consulardiptychen und verwandte Denkmäler, (Studien zur spätantiken Kustgeschichte) 2 (Berlin, 1929). The book is now available in Italian with an exhaustive bibliographical addition: Richard Delbrück, Dittici consolaritardoantichi, ed. trans. Marilena Abbatepaolo, (Biblioteca tardoantica) 1 (Bari, 2009). For more up-to-date reading on the phenomenon: Eburnea Dyptica, ed. David; Massimiliano David, "Ristudiare i dittici eburnei," in Marilena Abbatepaolo, Parole d'avorio. Fonti letterarie e testiper lo studio dei dittici eburnei, (Biblioteca tardoantica) 8 (Bari, 2012), pp. 5-10.

55 On the fate of diptychs in the Middle Ages: Anthony Cutler, "Il linguaggio visivo dei dittici eburnei: forma, funzione, produzione, ricezione," in Eburnea Dyptica, ed. David, pp. 131-61; Fulvio Cervini, "Le vie del classicismo tra iconografie e linguaggi," in Eburnea Dyptica, ed. David, pp. 163-86. On the liturgical reuse of late antique diptychs, most recently: Abbatepaolo, Parole d'avorio, pp. 67-95 (with references). 
has hindered its identification. ${ }^{56}$ The recent cleaning it has undergone permits us to analyse this detail more carefully, allowing us to recognize the animals as two small lions. ${ }^{57}$ It would be difficult not to connect this element to the heraldic meaning that the lion's image held for the budding Norman royalty. A pair of addorsed lions is embroidered on the Mantle of Roger (Royal Tiraz, around 1133/34, Kunsthistorisches Museum Vienna, Weltliche Schatzkammer). Another pair of rampant lions appears in the large mosaic that occupies the entrance to the Palatine Chapel, as well in the mosaics of the so-called King Roger Hall, a room probably of ceremonial use.

It is somewhat surprising that this lion reference is not associated with the main figure of the game - that is to say, with the king - but rather with the queen. This apparent anomaly may be linked to the identity of the first recipient of the game set, who was perhaps a woman. In this light, the first wife of Roger II, Alberia (Albidia/Elvira) comes quickly to mind. As is known, the sovereign was particularly attached to this consort, whom he had married in his youth. Upon her death in February 1135, it seems he was so shaken that he did not remarry immediately, as was the custom in such circumstances. Alberia is also the only one among Roger's three wives to whom the sources lend a personality: Alexander of Telese defines her as "pious and very charitable." 58 A few decades later, the chronicler Petrus de Ebulo described the marriage of the Dux Rogerius to the inclita Albidia as the royal anointing of Roger and of his desire to generate a royal lineage. ${ }^{59}$ The image illustrating this particula of the text includes an interesting portrait of the couple: Roger II, on horseback, presents a palm tree to his future wife, enthroned (Petrus de Ebulo, Liber ad honorem Augusti, 1195-1197, Bern, Burgerbibliothek, MS. 120, II, fol. 96r). Alberia had Hispanic origins, being the daughter of Alfonso vi of León and Castile and

$5^{6}$ The slightly different dimensions of this figure compared to the other queen led me to believe that the piece could have been a replacement made at a later time, see: Speciale, "Ludus scachorum," p. 208.

57 This observation came out of a conversation with Azzurra Palazzo. Adolph Goldschmidt, the only one to have attempted to identify the figures thought they were two small dogs: Goldschmidt, Elfenbeinskulpturen, p. 46.

58 "religionis gratia atque elemosinarum largitione fertur plurimum enituisse. Qua defuncta Rex ipse ita meroris contritus est amaritudine ut multis se diebus intra cameram recludens, exceptis eius privatis obsecutoribus non apparuerit." See: Alexandri Telesini abbatis Ystoria Rogerii regis Sicilie, Calabrie atque Apulie, ed. Ludovica De Nava, hist. com. Dione Clementi, (Fonti per la storia d'Italia) 112 (Rome, 1991), III, 1, p. 59.

59 Petrus de Ebulo, Liber ad honorem Augusti sive de rebus Siculis, Codex 120 II der Burgerbibliothek Bern 1, eds. Theo Kölner, and Marlis Stähli (Zurich, 1994), pp. 37-38. 
his fourth wife, Isabella, a Muslim who converted to Christianity. ${ }^{60}$ Indeed, the earliest documentation of chess sets among the personal items of aristocratic ladies come from the Iberian region. ${ }^{61}$ The smaller queen of the Charlemagne chess set, who shows traits of the new Norman kingship in her clothing and attributes, could reflect the personality and the cosmopolitan education of this sovereign.

In the king-pieces, the gesture of the figure, holding the sceptre in his left hand and resting the index finger of the other hand on it (figures. 9.1, 9.3), is an explicit allusion to the role, prerogatives, and insignia of kingship. The gesture has no precedents or replicas in the illustrated chess tradition. Nor does it find any parallel in the more general context of images of authority in the Latin West, where representations of the sceptre in the hands of the sovereign are certainly not rare, especially on coins and seals. ${ }^{62}$

In the iconography of chess, the attributes and gestures of the king-piece draw inspiration from military types. The most common attribute of the sovereign is not the sceptre but the sword. In the 12th-century Lewis chessmen, which bear many similarities to the Saint-Denis set, the sovereign holds the weapon resting on his knees. ${ }^{63}$ In other cases, the king holds the hilt of the unsheathed sword in his right hand. ${ }^{64}$ An evident war connotation also

6o For Alberia, see: Hubert Houben, "Elvira," in Dizionario Biografico degli Italiani 42 (Rome, 1994), pp. 532-33.

61 Speciale, "Il gioco come Status Symbol," pp. 242-43 (with references).

62 For images of seals and their value, see: Michel Pastoureau, "Les sceaux et la fonction sociale des images," in L'image. Fonctions et usage des images dans l'Occident médiéval. Atti del VI Workshop Internazionale sulle Società Medievali, Erice, 17-23 ottobre 1992, eds. Jérôme Baschet, and Jean-Claude Schmitt (Paris, 1996), pp. 275-308. For a synthesis of the preliminary studies on the official iconography of the Norman regnum extended to seals, see: Mirko Vagnoni, Le rappresentazioni del potere. La sacralità regia dei Normanni di Sicilia: un mito? (Bari, 2012), pp. 102-07.

63 This representative composition, documented for the first time in the image of the king that appears on the gilt bronze forehead plate of Agilulf (Florence, Museo Nazionale del Bargello), seems to also have a place in the Carolingian figural art. For the origin and evolution of this iconographic motif, see: Speciale, Immagini per la storia, pp. 16-21.

64 Highlighting this composition are two isolated pieces, both decidedly made later than the Charlemagne set - one belonging to the collection of the Archeological Museum of Ravenna, and the other to the Hohenzollern Collection. Both pieces are damaged, but must have originally shown unsheathed swords: Speciale, Immagini per la storia, p. $5^{8}$, fig. 41 (with references); Speciale, "Il gioco come status-symbol," p. 258, fig. 13. 
characterizes the sovereign who takes up arms, carved on the forehead of a king-piece (Louvre, inv. OA 6o62) produced in a southern Italian workshop around the same time as the Charlemagne set. ${ }^{65}$

In comparison to these, the king's ostentatious display of the sceptre in the Parisian chess set appears novel. The gesture is mirrored between the two king figures; this leads us to believe that this iconographic detail had a particular meaning for the creator of the Saint-Denis chess set. Again, the thought goes to the Norman court and the institution of the Regnum. In this context, it is difficult not to compare the double display of the sceptre of Charlemagne's chess set with a passage from the epigraph celebrating the inauguration of the Royal Palace of Palermo's Horologium. The instrument, a complex water mechanism, was commemorated with a dedication in three languages - Latin, Greek, and Arabic - attributing it to the sovereign and his will to regulate time. The three versions of the text are not perfectly identical: more than a literal translation of the same composition, each presents a different celebration of the patron and his endeavour.66

The most interesting section of this inscription is the one in Greek ${ }^{67}$ :

O new marvel, the mighty prince, King Roger, to whom God gave the sceptre, who controls the flow of the liquid element, delivering the exact knowledge of the hours of the year. The 12th year of his empire, in the month of March, index 5, year 6650.68

Here, the date and the titles of the sovereign take up the formulas of Greek diplomas produced in the royal Norman chancellery. The less stereotyped

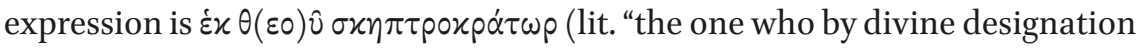
holds the sceptre"). ${ }^{69}$ Seen in this light, the carvings of the two king-pieces of

65 Speciale, "84. Re," pp. 464-65 (with references).

66 Jeremy Johns, "Iscrizioni arabe nella Cappella Palatina," in La Cappella Palatina a Palermo, ed. Beat Brenk, (Mirabilia Italiae) 17 (Modena, 2010), pp. 353-86.

67 The transcription is the most recent one proposed by: Johns, "Iscrizioni," pp. 382-83.

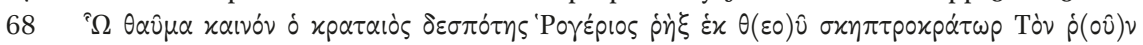

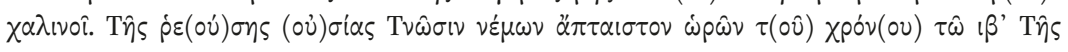

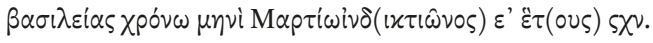

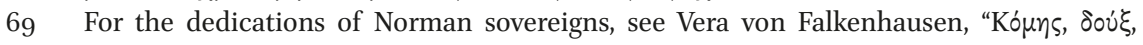
$\pi \rho^{\prime} \gamma \varkappa \iota \psi, \rho ' \xi \xi, \beta \alpha \sigma \iota \lambda \varepsilon \varepsilon^{\prime}$. Zu den griechischen Titeln der normannischen Herrscher in

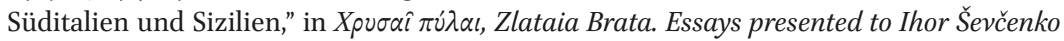
on his Eightieth Birthday by his colleagues and students 1, eds. Peter Schreiner, and Olga Strakhov, Palaeoslavica 10/1 (2002), 79-93. I am very grateful to Vera von Falkenhausen for the exchange of views and for giving me this essay. 
the Charlemagne set embody almost literally the royal image of the Norman king, reaffirming once again the hypothesis that this extraordinary game set comes from Palermo and was perhaps among the furnishings of its great palace.

If my hypothesis is correct, the chess pieces from Saint-Denis are a fragment of the dispersed treasure of the Royal Palace of Palermo and were created on the occasion of the royal consecration of Roger II.

The pieces were certainly used as a normal set, for play, but it is difficult to believe that such an expensive and sophisticated artifact reflected a symbolism limited only to the private sphere. The dimensions, the material in which the pieces are carved, and above all the subtle transposition of the game figures into images demonstrate quite the opposite.

The creation of this extraordinary figured chess set offers one possible answer to the problem of the meaning and functions of the royal portrait. The ostentatious display of the sceptre by the two kings perfectly corresponds to the definition of Roger II as skeptokrator in the dedicatory inscription of the Horologium of the Royal Palace, a decidedly public work. Unfortunately, the image that was to accompany the automaton has disappeared. How much the 'private' image of a king-piece might reflect this missing image from the dedication remains an open problem - but are we sure that in the representative forms of medieval royalty there was a clear border between public image and private image?

\section{Bibliography}

\section{Primary Sources}

Alexandri Telesini abbatis Ystoria Rogerii regis Sicilie, Calabrie atque Apulie, ed. Ludovica De Nava, hist. Com. Dione Clementi (Fonti per la storia d'Italia) 112 (Rome, 1991).

Petrus de Ebulo, Liber ad honorem Augusti sive de rebus Siculis, Codex 120 II der Burgerbibliothek Bern 1, eds. Theo Kölner, and Marlis Stähli (Zurich, 1994).

\section{Secondary Sources}

Amatuccio, Giovanni, "Fino alle mura di Babilonia'. Aspetti militari della conquista normanna del Sud," Rassegna storica Salernitana 30 (1998), 7-49.

Angelova, Diliana, "The Ivories of Ariadne and Ideas about Female Imperial Authority in Rome and Early Byzantium," Gesta 43/1 (2004), 1-15.

Bardiès-Fronty, Isabelle, "101. Pièce d'échecs: roi," in Art dujeu, jeu dans l'art. De Babylone à l'Occident médiéval. Musée de Cluny - Musée national du Moyen Âge, 28 novembre 2012-4 mars 2013 (Paris, 2012), p. 108. 
Barral I Altet, Xavier, En souvenir du roi Guillaume. La broderie de Bayeux. Stratégies narratives et vision médiévale du monde (Paris, 2016).

Bergman, Robert, "A School of Romanesque Ivory Carving in Amalfi," Metropolitan Museum Journal 9 (1974), 163-86.

Bergman, Robert, The Salerno Ivories. Ars Sacra from Medieval Amalfi (Cambridge, Eng., 1980).

Boek, Elena N., "The politics of visualizing an imperial demise: transforming a Byzantine chronicle into a Sicilian visual narrative," Word \& image 25 (2009), 243-57.

Bologna, Ferdinando, Opere d'arte nel Salernitano dal XII al XVIII secolo (Napoli, 1955).

Bologna, Ferdinando, "Avori medioevali da Amalfi a Salerno, senza enigmi," in L'Enigma degli avori medievali da Amalfi a Salerno, ed. Ferdinando Bologna, 2 vols (Napoli, 2008), 1:21-97.

Braca, Antonio, "Lavori in avorio in Amalfi medievale: considerazioni e ipotesi," Rassegna del Centro di Cultura e Storia amalfitana n.s. 3 (1993), 111-28.

Braca, Antonio, Gli avori medievali del Museo Diocesano di Salerno (Salerno, 1994).

Braca, Antonio, Il Duomo di Salerno. Architetture e culture artistiche del medioevo e dell'Età Moderna (Società Salernitana di Storia Patria, Collana di Studi Storici Salernitani) 19 (Salerno, 2003).

Braca, Antonio, "Intorno alla cassetta di avorio di Farfa. Il cimelio, il donatore e la cassetta amalfitana," in L'Enigma degli avori medievali da Amalfi a Salerno, ed. Ferdinando Bologna, 2 vols (Napoli, 2008), 1:161-201.

Capaldo, Lello, "Il Trono di Federico II," in Atti dell'Accademia Pontaniana n.s. 47 (1998), 73-9o.

Cassanelli, Roberto, "I modi della trasmissione. Dai tesori altomedievali ai musei d'arti applicate," in Eburnea Dyptica. I dittici d'avorio tra Antichità e Medioevo, ed. Massimiliano David (Bari, 2007), pp. 317-29.

Celentano, Cinzia, "Schede 166a, 166b-c," in Caserta e la sua Reggia: Il Museo dell'Opera e del territorio (Napoli, 1995), pp. 210-12.

Cervini, Fluvio, "Le vie del classicismo tra iconografie e linguaggi," in Eburnea Dyptica. I dittici d'avorio tra Antichità e Medioevo, ed. Massimiliano David (Bari, 2007), pp. 163-86.

Cordez, Philippe, "O joco de xadrez: imagem, poder e igreja (fin do século X - início do século XII)," Revista de História 165 (2011), 93-120.

Curzi, Gaetano, Arredi lignei medievali. L'Abruzzo e l'Italia centromeridionale. Secoli XIIXIII (Cinisello Balsamo, 2007).

Cutler, Anthony, The Craft of Ivory. Sources, Techniques and Uses in the Mediterranean World:A.D. 200-1200 (Washington, D.C., 1985).

Cutler, Anthony, The Hand of the Master. Craftmanship, Ivory and Society in Byzantium (gth-IIth Centuries) (Princeton, 1994). 
Cutler, Anthony, "Il linguaggio visivo dei dittici eburnei: forma, funzione, produzione, ricezione," in Eburnea Dyptica. I dittici d'avorio tra Antichità e Medioevo, ed. Massimiliano David (Bari, 2007), pp. 131-61.

Cutler, Anthony, "The fabric, facture and enduring enigma of the Salerno ivories," in The Salerno Ivories: objects, histories, contexts, eds. Francesca Dell'Acqua, Anthony Cutler, Herbert L. Kessler, Avinoam Shalem, and Gerhard Wolf (Berlin, 2016), pp. 11-19.

David, Massimiliano, "Ristudiare i dittici eburnei," in Marilena Abbatepaolo, Parole d'avorio. Fonti letterarie e testi per lo studio dei dittici eburnei, (Biblioteca tardoantica) 8 (Bari, 2012), pp. $5^{-10 .}$

de Caylus, Anne-Claude-Philippe, Recueil d'antiquités égyptiennes, étrusques, grecques, romaines et gauloises 6 (Paris 1764).

De Juliis, Giuseppe, "Le vicende degli antichi avori della collezione Riccardi." Commentari n.s. 29 (1978), 144-56.

Delbrück, Richard, Die Consulardiptychen und verwandte Denkmäler, (Studien zur spätantiken Kustgeschichte) 2 (Berlin, 1929).

Delbrück, Richard, Dittici consolari tardoantichi, ed. trans. Marilena Abbatepaolo, (Biblioteca tardoantica) 1 (Bari, 2009).

de Montesquiou-Fezenzac, Blaise, Le Trésor de Saint-Denis 2 (Paris 1977).

Die Chronik von Montecassino, ed. Hartmut Hoffmann, MGH Scriptores 34 (1980).

D’Onofrio Mario, and Pace, Valentino, La Campania, Italia romanica 4 (Milano, 1981).

Doublet, Jean, Histoire de l'Abbaye de S. Denys en France (Paris 1625).

du Mersan, Marion, Histoire du Cabinet des Médailles, antiques et pierres gravées, avec une notice sur la Bibliothèque Royale et une description des objets exposés dans cet établissement (Paris, 1838).

Eales, Richard, "The Game of Chess: an Aspect of Medieval Knightly Culture," in The Ideals and Practice of Medieval Knighthood (Woodbridge, 1986), pp. 12-34.

Ebitz, David, "Secular to sacred: the transformation of an oliphant in the Musée de Cluny," Gesta 25 (1986), 31-38.

Eburnea Dyptica. I dittici d'avorio tra Antichità e Medioevo, ed. Massimiliano David (Bari, 2007).

Fillitz, Hermann, "Tesoro imperiale," in Federico II. Enciclopedia Fridericiana 2 (Roma, 2006), pp. 824-29.

Frugoni, Chiara, "Das Schachspiel in der Welt des Jacobus de Cessolis," in Das Schachbuch des Jacobus de Cessolis. Codex Palatinus Latinus 961, (Codices e Vaticanis Selecti) 74 (Zurich, 1988), pp. 35-77.

Gaborit-Chopin, Danielle, "Échecs de Charlemagne," in Le trésor de Saint-Denis. Musée du Louvre, Paris, 12 mars-17 juin 1991 (Paris, 1991), pp. 132-41.

Gaborit-Chopin, Danielle, Ivoires médiévaux, Ve-XVe siècle. Musée du Louvre, Département des Objets d'Art. Catalogue (Paris, 2003). 
Gaborit-Chopin, Danielle, "Pedine e scacchi," in Gli avori del Museo Nazionale del Bargello, ed. Ilaria Ciseri (Milano, 2018), pp. 153-70.

Gaborit-Chopin, Danielle, "Placca centrale di un Pentittico con imperatrice (Ariadne)," in Gliavori del Museo Nazionale del Bargello, ed. Ilaria Ciseri (Milano, 2018), pp.51-54.

Gamer, Helena M., "The Earliest Evidence of Chess in western literature: the Einsiedeln Verses," Speculum 29 (1954) 734-50.

Gandolfo, Francesco, La scultura normanno-sveva in Campania. Botteghe e modelli, (Fonti e studi) 9 (Roma, 1999).

Goldschmidt, Adolph, Die Elfenbeinskulpturen aus der Romanischen Zeit, XI.-XIII. Jahrhunderts (Berlin 1926).

Grabar, André, "Thrônes épiscopaux du XIe et XIIe siècles en Italie méridionale," Wallraf-Richartz-Jahrbuch 16 (1954), 7-52.

Guérin, Sarah M., "The tusk: origins of the raw material for the Salerno ivories," in The Salerno Ivories: objects, histories, contexts, eds. Francesca Dell'Acqua, Anthony Cutler, Herbert L. Kessler, Avinoam Shalem, and Gerhard Wolf (Berlin, 2016), pp. 21-29.

Houben, Hubert, "Elvira," in Dizionario Biografico degli Italiani 42 (Rome, 1994), pp. $532-33$.

Inventario e stima della libreria Riccardi. Manoscritti e edizioni del XV secolo (Firenze 1810).

Ivoires: de l'Orient ancien aux temps modernes, eds. Annie Caubet, and Danielle Gaborit-Chopin (Paris, 2004).

Johns, Jeremy, "Iscrizioni arabe nella Cappella Palatina," in La Cappella Palatina a Palermo, ed. Beat Brenk, (Mirabilia Italiae) 17 (Modena, 2010), pp. 353-86.

Lucà, Santo, "Dalle collezioni manoscritte di Spagna: libri originari o provenienti dall'Italia greca medievale," Rivista di studi bizantini e neoellenici 44 (2007), 39-96.

Makariou, Sophie, "Le jeu d'échecs, une pratique de l'aristocratie entre Islam et chrétienté des IXe-XIIIe siècles," in Chrétiens et musulmans autour de l'an 110o. Actes des $36^{e}$ Journées Romanes de Cuxa, Les cahiers de Saint-Michel de Cuxa 35 (2003/o4), 127-40.

Müller, Rainer A., "Il gioco degli scacchi come metafora della civiltà medievale," Ludica 1 (1995), 114-25.

Murray, Harold J. R., History of Chess (Oxford, 1913, repr. New York, 1965).

Nicolle, David C., Arms and armour of the Crusading Era: 1050-1350, 2 vols (New York, 1988).

Pace, Valentino, "Le pertinenze bizantine degli affreschi campani di Santa Maria di Foroclaudio," Storia dell'arte 34 (1978), 207-09.

Pace, Valentino, "La cattedrale di Salerno. Committenza, programma e valenze ideologiche di un monumento di fine XI secolo nell'Italia meridionale," in Desiderio di Montecassino e l'Arte della Riforma Gregoriana, ed. Faustino Avagliano (Montecassino, 1997), pp. 189-230. 
Pace, Valentino, "La Campania," in La scultura d'età normanna tra Inghilterra e Terrasanta. Questioni storiografiche, ed. Mario D’Onofrio (Fonti e Studi) 11 (Roma 2001), pp. 71-104.

Pace, Valentino, "Le pertinenze bizantine degli affreschi campani di Santa Maria di Foroclaudio," in Valentino Pace, Arte medievale in Italia meridionale 1. Campania, (Nuovo medioevo) 70 (Napoli, 2006), pp. 117-21.

Pace, Valentino, "La cattedrale di Salerno. Committenza, programma e valenze ideologiche di un monumento di fine XI secolo nell'Italia meridionale," in Valentino Pace, Arte medievale in Italia meridionale 1. La Campania, (Nuovo Medioevo) 70 (Napoli, 2007), pp. 69-9o.

Pace, Valentino, "Maniera saracena in Italia meridionale: l'olifante Basilewsky," Palazzo Madama. Studi e notizie 4-3 (2014-15), 66-73.

Pastoureau, Michel, L'Échiquier de Charlemagne. Un jeu pour ne pas jouer (Paris, 199o). Pastoureau, Michel, Pièces d'Échecs. Bibliothèque Nationale. Cabinet des médailles et antiques, 7 juin-3o septembre 1990 (Paris, 1990).

Pastoureau, Michel, "Les sceaux et la fonction sociale des images," in L'image. Fonctions et usage des images dans l'Occident médiéval. Atti del VI Workshop Internazionale sulle Società Medievali, Erice, 17-23 ottobre 1992, eds. Jérôme Baschet, and JeanClaude Schmitt (Paris, 1996), pp. 275-308.

Pastoureau, Michel, "L'arrivo degli scacchi in Occidente. Storia di una acculturazione difficile," in Michel Pastoureau, Medioevo simbolico (Paris 2004; repr. Rome, 2005), pp. 247-68.

Perta, Giuseppe, "La 'Cassetta di Farfa' e l'itinerario mediterraneo dei de comite Maurone," Annali della Pontificia Insigne Accademia di Belle Arti e Lettere dei Virtuosi al Pantheon 16 (2016), 373-92.

Putaturo Murano, Antonella, "Arredi lignei," in Insediamenti verginiani in Irpinia. Il Goleto, Montevergine, Loreto, ed. Vincenzo Pacelli (Cava dei Tirreni, 1988), pp. $185-87$.

Sanvito, Alessandro, "Bianco e nero o rosso e verde?," L'Italia scacchistica 943 (1984), $143-46$.

Scerrato, Umberto, "Arte," in Gli arabi in Italia, ed. Francesco Gabrieli and Umberto Scerrato (Milan, 1979), pp. 275-574.

Ševčenko, Ihor, "The Madrid manuscript of the chronicle of Skylitzes in the light of its new dating," in Byzanz und der Westen. Studien zur Kunst des europäischen Mittelalters, ed. Irmgard Hutter, (Österreichische Akademie der Wissenschaften / Philosophisch-Historische Klasse) 432 (Wien, 1984), pp. 117-30.

Shalem, Avinoam, Islam Christianized. Islamic Portable Objects in the Medieval Church Treasuries of the Latin West (Ars Faciendi, Beiträge und Studien zur Kunstgeschichte) 7, 2nd ed. (Frankfurt, 1998).

Shalem, Avinoam, The Oliphant. Islamic objects in Historical Context (Leiden, 2004). 
Silvestro, Silvia, "La Puglia," in La scultura d'età normanna tra Inghilterra e Terrasanta. Questioni storiografiche, ed. Mario D’Onofrio (Fonti e Studi) 11 (Roma, 2001), pp. $105^{-3} 8$.

Speciale, Lucinia, Montecassino e la Riforma Gregoriana. L'Exultet Barb. lat. 592, (Studi di arte medievale) 3 (Rome, 1991), pp. 119-46.

Speciale, Lucinia, "Il gioco dei Re. Intorno agli 'Scacchi di Carlo Magno,' " in Medioevo: la Chiesa e il Palazzo. Atti del Convegno internazionale di studi, Parma, 20-24 settembre 2005, ed. Arturo C. Quintavalle (I Convegni di Parma) 8 (Parma, 2007), pp. 238-48.

Speciale, Lucinia, "84. Re (pezzo per il gioco degli scacchi)," in L'Enigma degli avori medievali da Amalfi a Salerno, ed. Ferdinando Bologna, 2 vols (Napoli, 20o8), 2:464-65.

Speciale, Lucinia, "86. oliphante," in L'Enigma degli avori medievali da Amalfi a Salerno, ed. Ferdinando Bologna, 2 vols (Napoli, 2008), 2:470-73.

Speciale, Lucinia, "Ludus scachorum: il gioco dei re. Forma e iconografia degli scacchi tra l'Italia e l'Europa," in L'Enigma degli avori medievali da Amalfi a Salerno, ed. Ferdinando Bologna, 2 vols (Napoli, 2008), 2:203-29.

Speciale, Lucinia, "Gli 'Scacchi di Carlo Magno' e non solo," in The "Amalfi" - "Salerno" Ivories and the Medieval Mediterranean. A Notebook from the Workshop Convened in Amalfi, December 10-13, 20o9, eds. Francesca Dell'Acqua, Herbert L. Kessler, Avinoam Shalem, and Gerhard Wolf (Amalfi, 2011), pp. 101-04.

Speciale, Lucinia, “Guerra e Pace. Ancora sugli 'Scacchi di Carlo Magno', in Tempi e forme dell'arte. Miscellanea di studi offerti a Pina Belli D'Elia, eds. Luisa Derosa, and Clara Gelao (Foggia, 2011), pp. 73-81.

Speciale, Lucinia, "Il libro decorato nella Puglia dell'alto medioevo. Qualche novità e qualche riflessione," in Bizantini, Longobardi e Arabi in Puglia nell'alto medioevo, Ventesimo Congresso internazionale di studio del Centro Italiano di studi sull'alto medioevo, Savelletri di Fasano (BR), 3-6 novembre 2011 (Spoleto, 2012), pp. 685-706.

Speciale, Lucinia, Immagini per la storia. Ideologia e rappresentazione del potere nel mezzogiorno medievale, (Fondazione 'Centro Internazionale di Studi sull'alto medioevo', Testi, studi, strumenti) 30 (Spoleto, 2014).

Speciale, Lucinia, "Il gioco come status-symbol. Gli scacchi tra formule rappresentative e testimonianze materiali," in Il gioco nella società e nella cultura dell'altomedioevo, Spoleto, 20-26 aprile 2017, Settimane di Studio della Fondazione Centro Italiano di Studi sull'Alto Medioevo 65 (Spoleto, 2018), pp. 241-53.

Speciale, Lucinia, "Il gioco di un re: gli Scacchi Di Carlo Magno," in Castrum Superius. Il Palazzo dei re normannni (Palermo. Fondazione Federico) 2 (Palermo, 2019), pp. 204-15.

Speciale, Lucinia, "S. Maria de episcopio a Ventaroli: le pitture murali più antiche," in Studi in onore di Giovanni Carbonara (in press).

Toesca, Pietro, "Un cimelio amalfitano," Bollettino d'arte 27 (1933-34), 537-43. 
Tsamakda,Vasiliki, The illustrated chronicle of Ioannes Skylitzes in Madrid (Leiden, 2002). Vagnoni, Mirko, Le rappresentazioni del potere. La sacralità regia dei Normanni di Sicilia: un mito? (Bari, 2012).

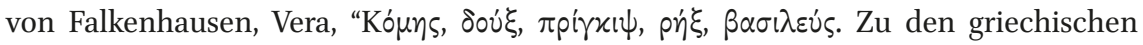

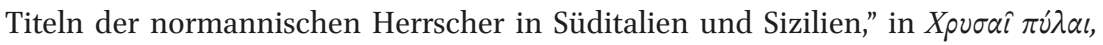
Zlataia Brata. Essays presented to Ihor Ševčenko on his Eightieth Birthday by his colleagues and students 1, eds. Peter Schreiner, and Olga Strakhov, Palaeoslavica 10/1 (2002), 79-93.

Williamson, Paul, "Review of Valentino Pace, Una Bibbia in avorio: Arte mediterranea nella Salerno dell'XI secolo (Milano, 2016)," The Burlington Magazine 169 (2017), p. 556 .

\section{Illustrations}
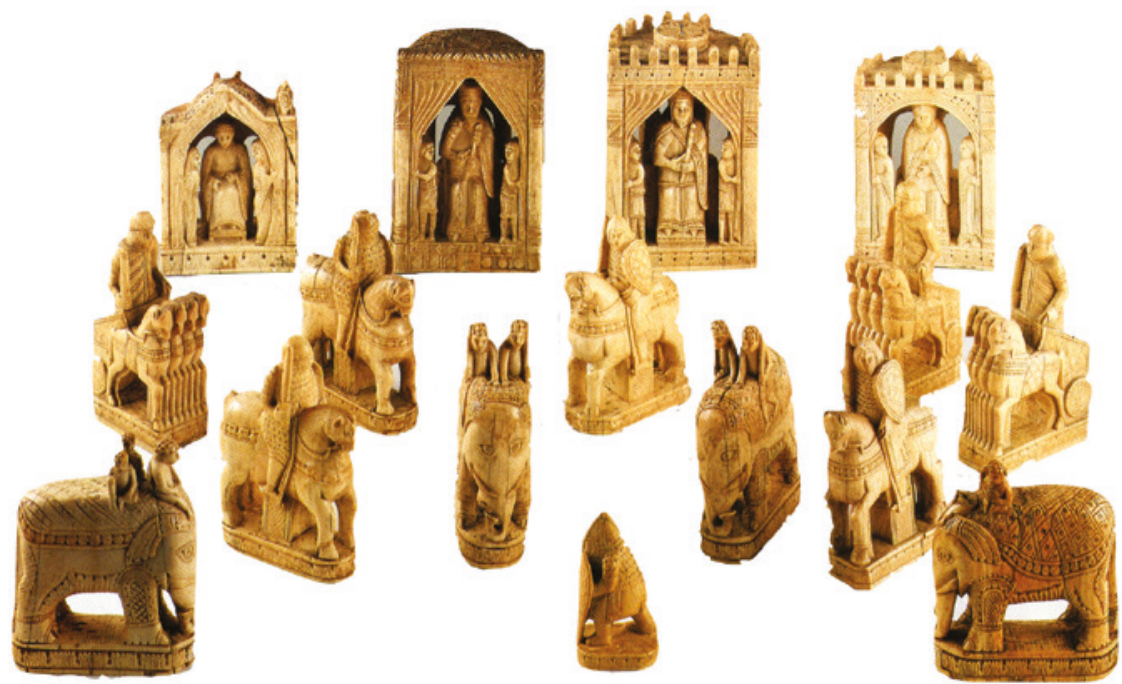

FIGURE 9.1 Paris, Bibliothèque Nationale de France, Cabinet des Médailles et Antiques, "Charlemagne's Chess set" PHOTOGRAPH COURTESY OF THE BNF, BEFORE RESTORATION 


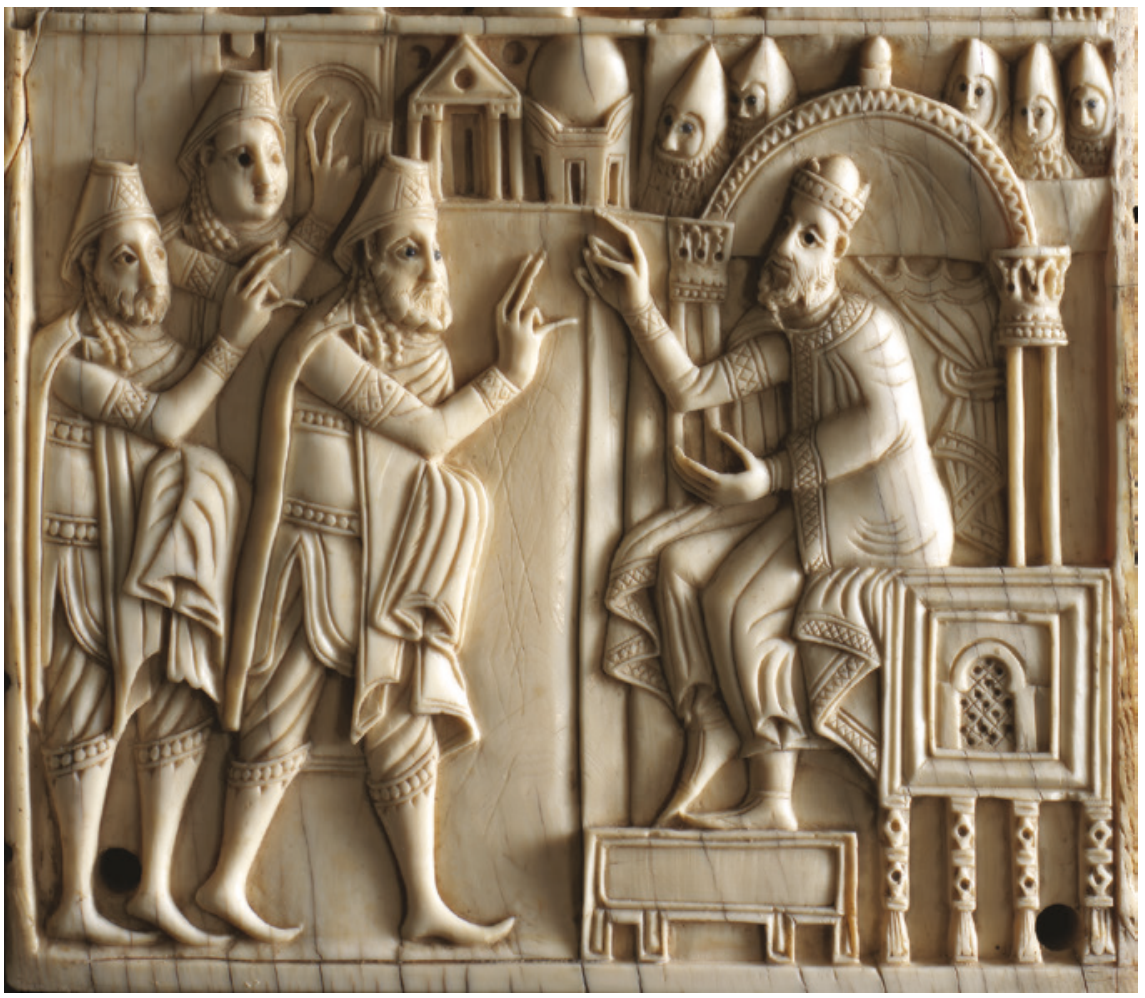

FIGURE 9.2 Salerno, Museum of the Cathedral, Salerno Ivories, Plaque Depicting Meeting between Herod and the Magi from New Testament Cycle COPYR MIBACT 2007 


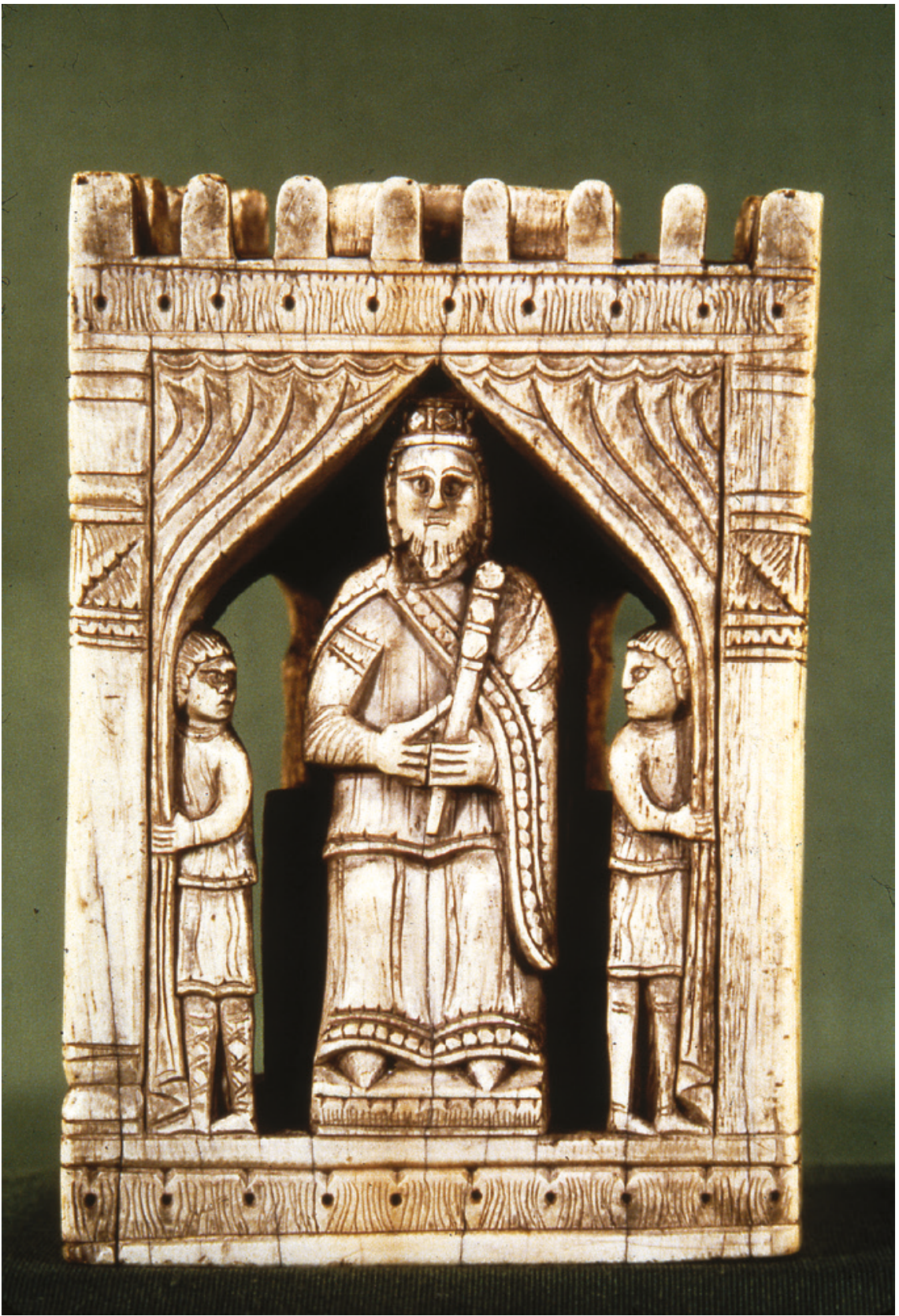

Figure 9.3 Paris, BnF, Cabinet des Médailles et Antiques, "Charlemagne’s Chess set" King (inv. 55.306)

PHOTOGRAPH COURTESY OF THE BNF, BEFORE RESTORATION 


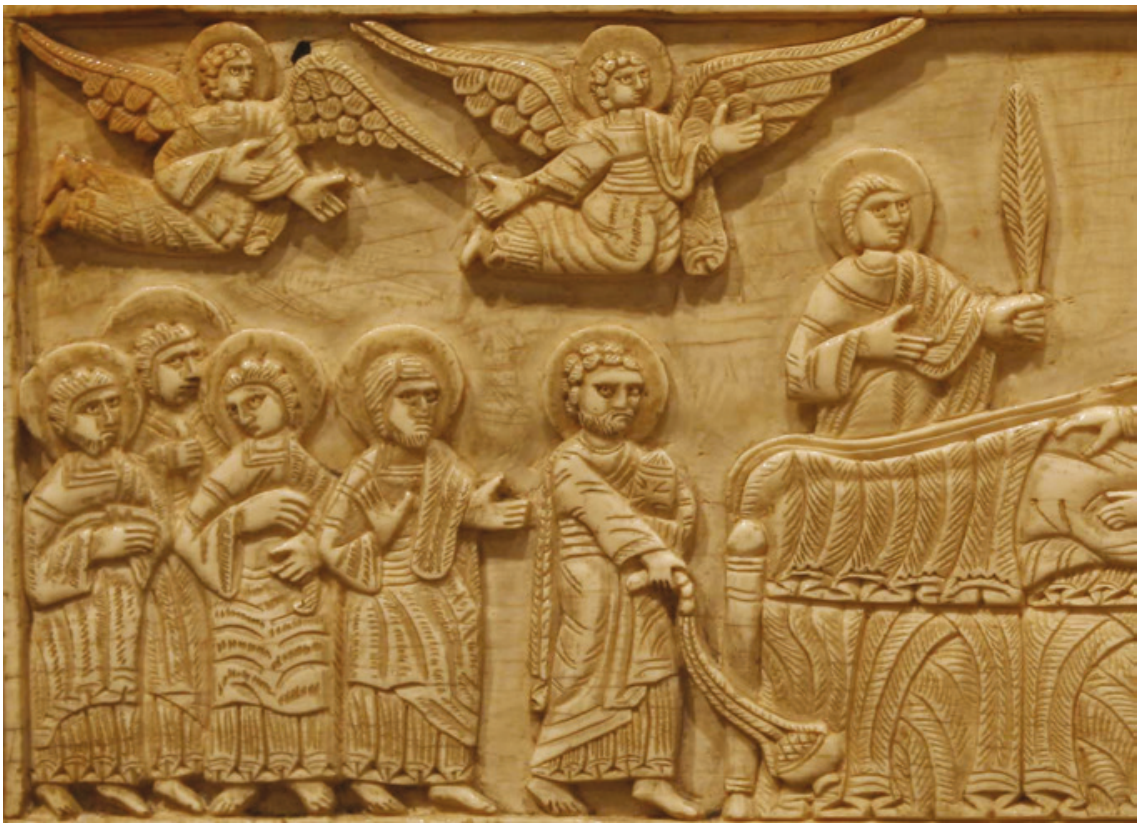

FIGU RE 9.4 Farfa Abbey, Museum, Farfa Casket 1072 a.q., Dormitio Virginis AFTER A. BRACA 


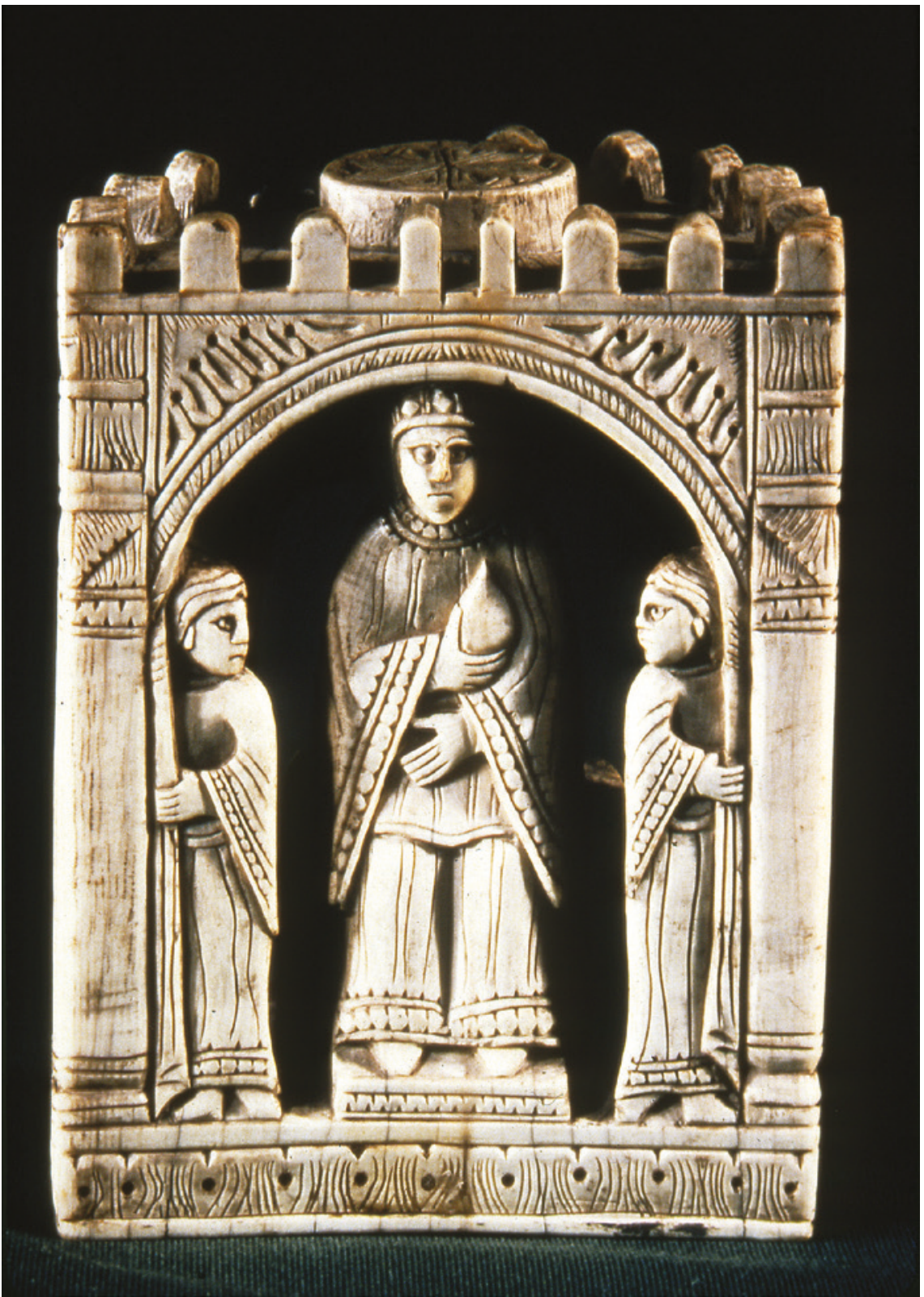

FIgURE 9.5 Paris, Bibliothèque Nationale de France, Cabinet des Médailles et Antiques, "Charlemagne's Chess set" Queen (inv. 55.310) PHOTOGRAPH COURTESY OF THE BNF, BEFORE RESTORATION 


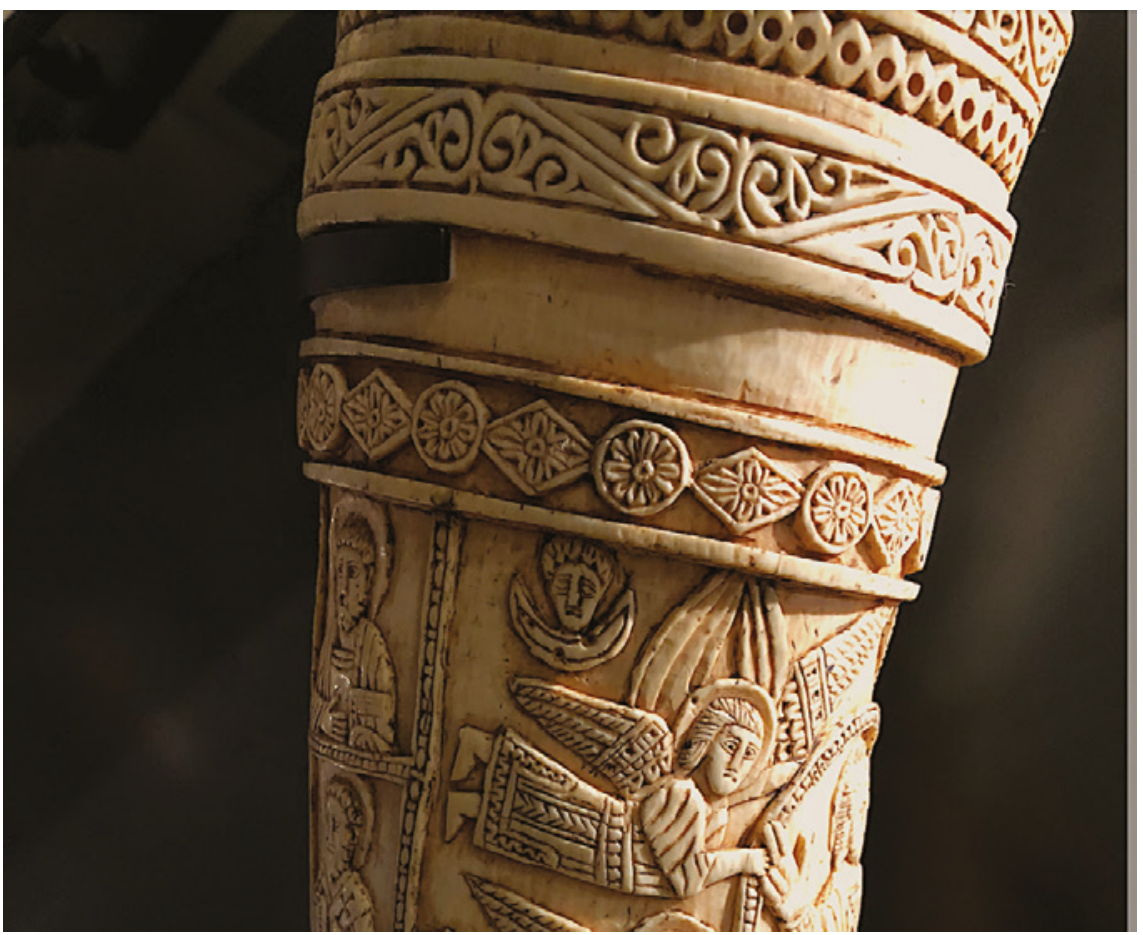

FIGURE 9.6 Paris, Musée Nationale du Moyen Âge - Thermes de Cluny, inv. CL13065, Oliphant from Saint-Arnould Abbey, Metz

PHOTOGRAPH COURTESY OF THE REUNION DES MUSÉES NATIONAUX 


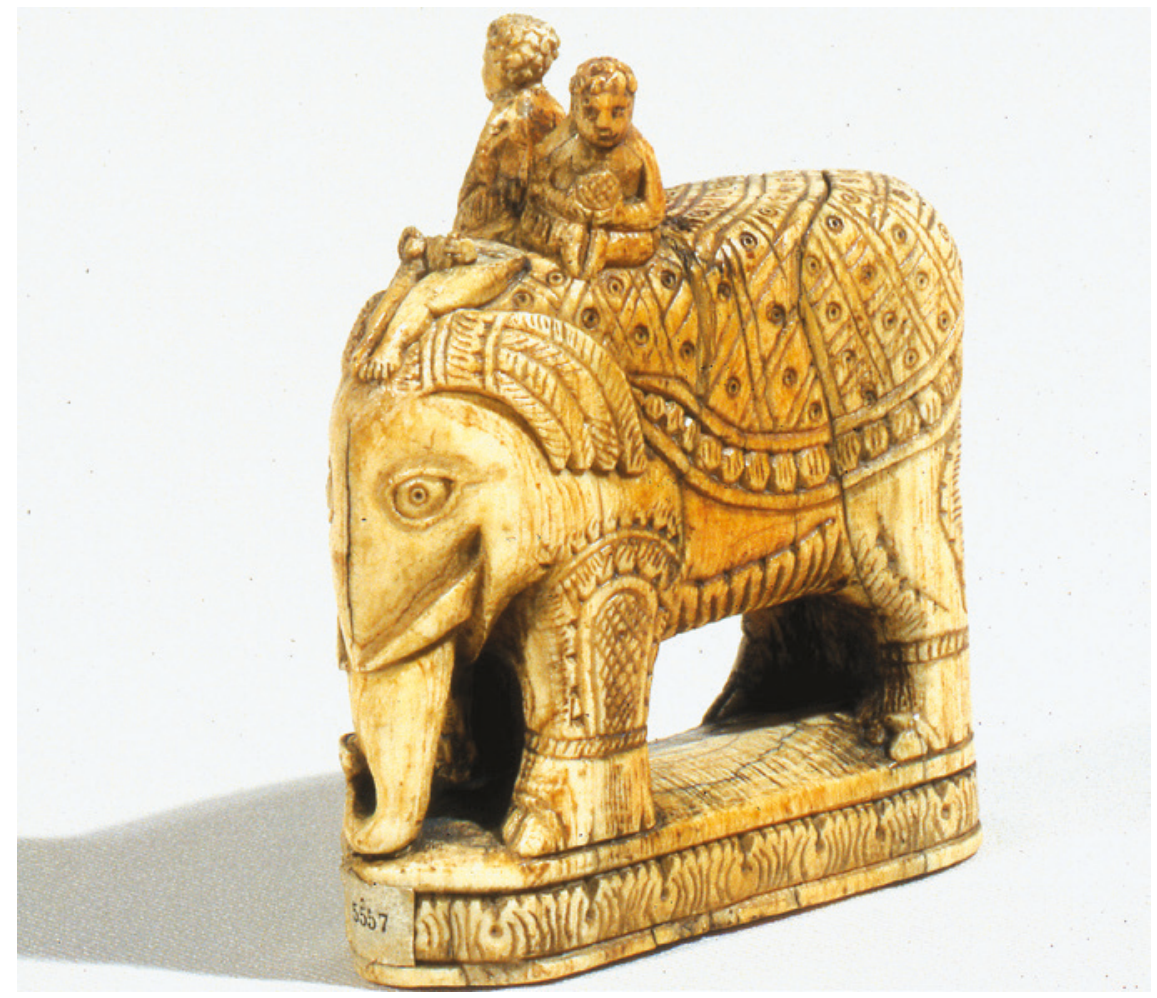

FIGURE 9.7 Paris Bibliothèque Nationale de France, Cabinet des Médailles et Antiques, "Charlemagne's Chess set", Bishop, Elephant with trhee mahouts (inv. 55·315) PHOTOGRAPH COURTESY OF THE BNF, BEFORE RESTORATION 


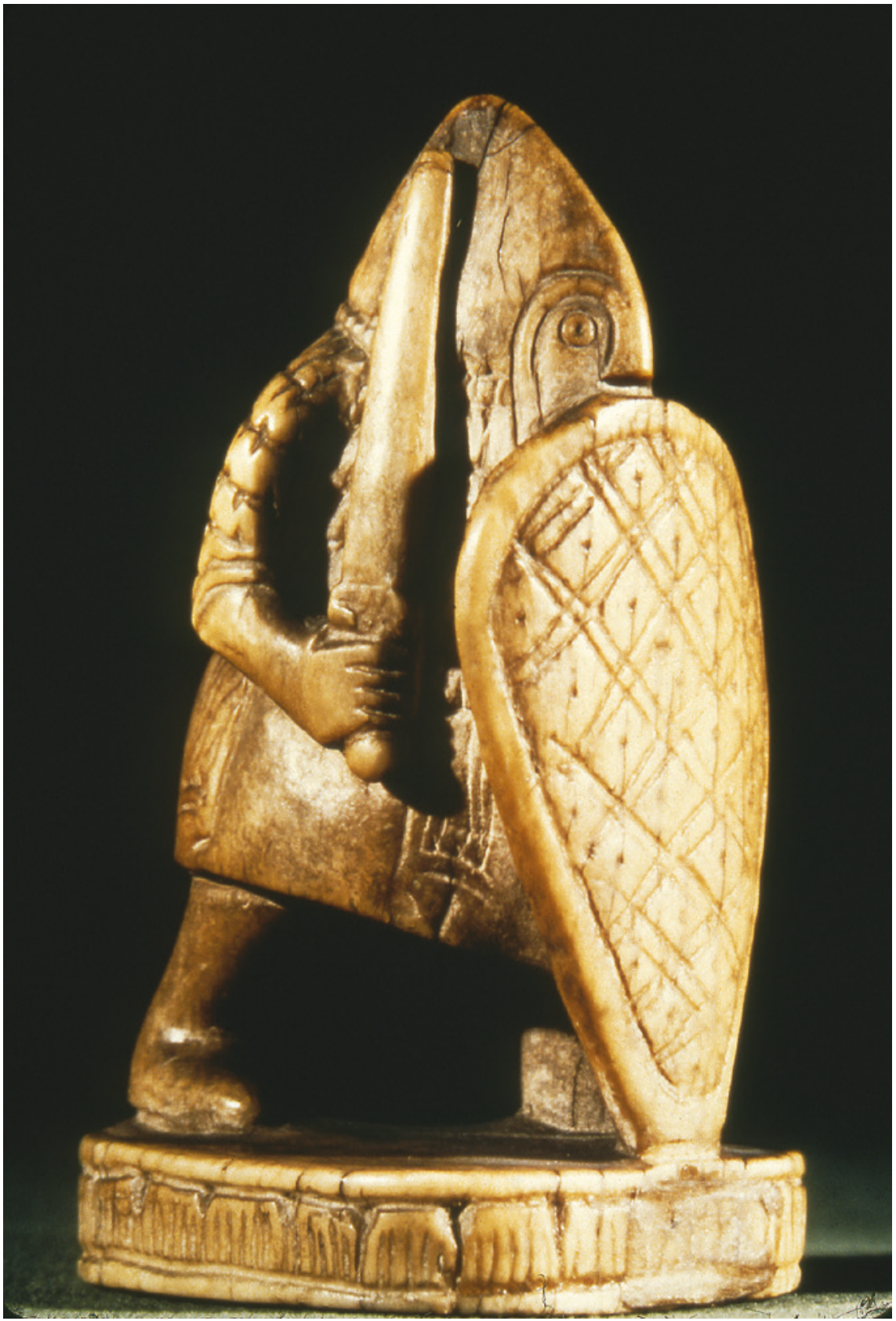

FIGURE 9.8 Paris Bibliothèque Nationale de France, Cabinet des Médailles et Antiques,

"Charlemagne's Chess set", Pawn (inv. 55323)

PHOTOGRAPH COURTESY OF THE BNF, BEFORE RESTORATION 


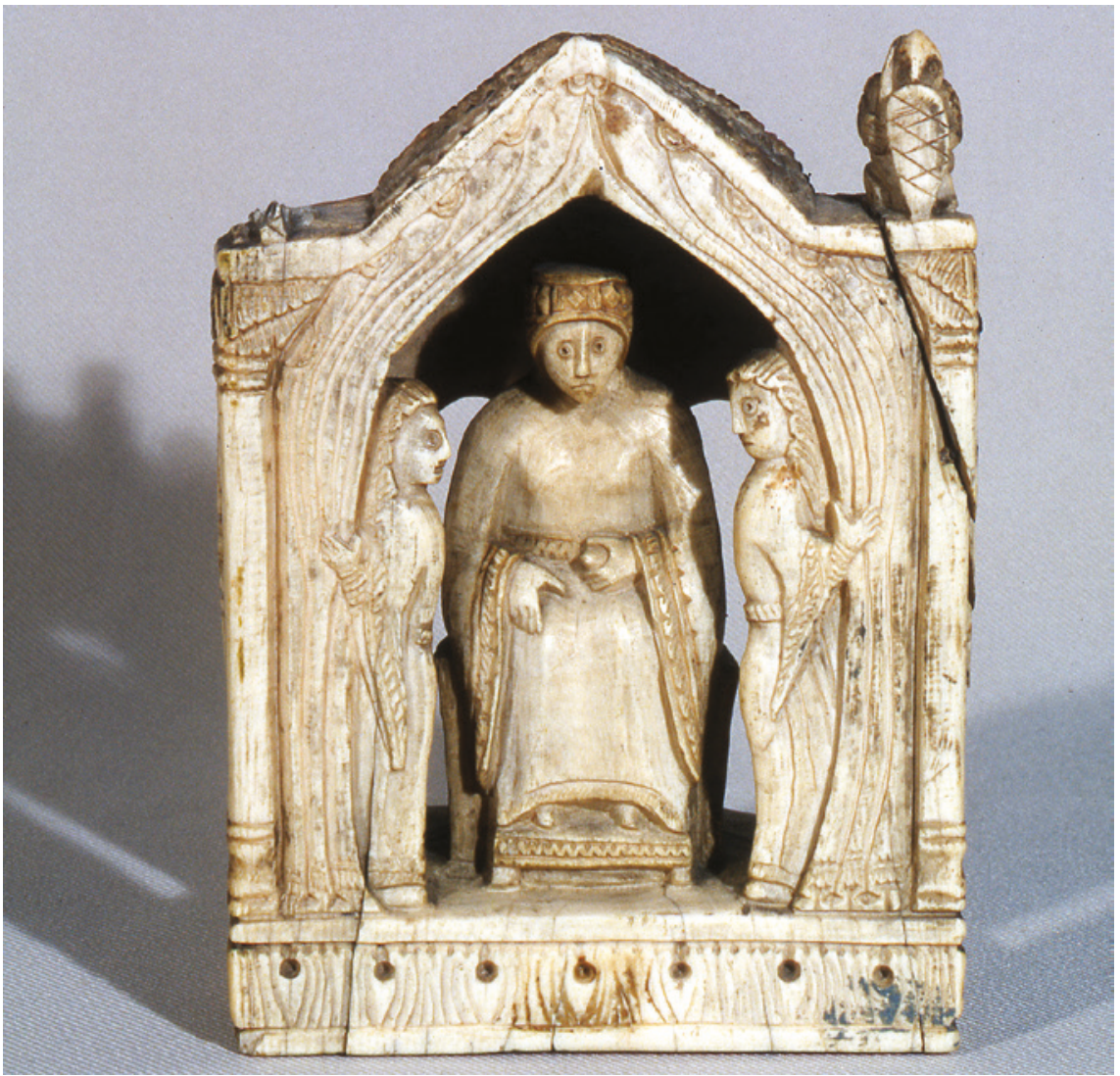

FIGURE 9.9 Paris Bibliothèque Nationale de France, Cabinet des Médailles et Antiques, "Charlemagne's Chess set", Queen (inv. 55.309) side A PHOTOGRAPH COURTESY OF THE BNF, BEFORE RESTORATION 


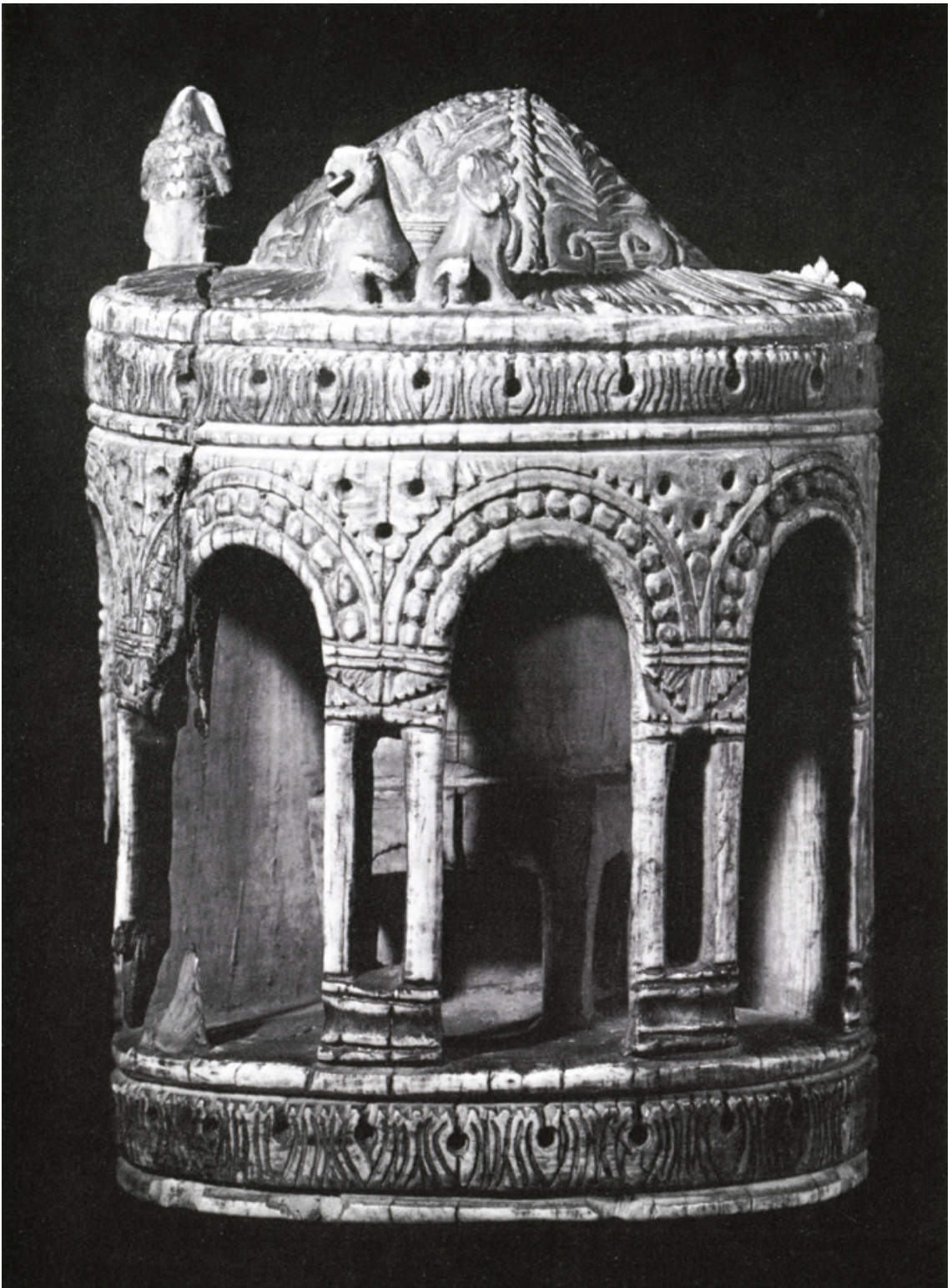

FIGURE 9.10 Paris Bibliothèque Nationale de France, Cabinet des Médailles et Antiques, "Charlemagne's Chess set", Queen (inv. 55309) side B PHOTOGRAPH COURTESY OF THE BNF, BEFORE RESTORATION 